\title{
QUEEN'S
UNIVERSITY
BELFAST
}

\section{Quantitative analysis of hydroxyapatite-binding plasma proteins in genotyped individuals with late-stage age-related macular degeneration}

Arya, S., Emri, E., Synowsky, S. A., Shirran, S. L., Barzegar-Befroei, N., Peto, T., Botting, C. H., Lengyel, I., \& Stewart, A. J. (2018). Quantitative analysis of hydroxyapatite-binding plasma proteins in genotyped individuals with late-stage age-related macular degeneration. Experimental Eye Research, 172, 21-29.

https://doi.org/10.1016/j.exer.2018.03.023

\section{Published in:}

Experimental Eye Research

Document Version:

Peer reviewed version

Queen's University Belfast - Research Portal:

Link to publication record in Queen's University Belfast Research Portal

\section{Publisher rights}

Copyright 2018 Elsevier.

This manuscript is distributed under a Creative Commons Attribution-NonCommercial-NoDerivs License

(https://creativecommons.org/licenses/by-nc-nd/4.0/), which permits distribution and reproduction for non-commercial purposes, provided the author and source are cited.

\section{General rights}

Copyright for the publications made accessible via the Queen's University Belfast Research Portal is retained by the author(s) and / or other copyright owners and it is a condition of accessing these publications that users recognise and abide by the legal requirements associated with these rights.

Take down policy

The Research Portal is Queen's institutional repository that provides access to Queen's research output. Every effort has been made to ensure that content in the Research Portal does not infringe any person's rights, or applicable UK laws. If you discover content in the

Research Portal that you believe breaches copyright or violates any law, please contact openaccess@qub.ac.uk. 
Quantitative analysis of hydroxyapatite-binding plasma proteins in genotyped individuals with late-stage age-related macular degeneration

Swati Arya ${ }^{a}$, Eszter Emri ${ }^{b}$, Silvia A. Synowsky ${ }^{c}$, Sally L. Shirran ${ }^{c}$, Neda Barzegar-Befroei ${ }^{d}$, Tunde Peto $^{\mathrm{b}, \mathrm{e}}$, Catherine H. Botting ${ }^{\mathrm{c}}$, Imre Lengyel ${ }^{\mathrm{b}, \mathrm{d}}$, Alan J. Stewart ${ }^{\mathrm{a}, *}$

${ }^{\text {a }}$ School of Medicine, University of St Andrews, St Andrews, KY16 9TF, UK.

${ }^{\mathrm{b}}$ Centre for Experimental Medicine, Queen's University Belfast, Belfast, BT9 7JL, UK.

${ }^{\mathrm{c}}$ Biomedical Sciences Research Complex, University of St Andrews, St Andrews, KY16 9ST, UK.

${ }^{\mathrm{d}}$ UCL Institute of Ophthalmology, University College London, London EC1V 9EL

${ }^{\mathrm{e}}$ Moorfields Eye Hospital, NHS Foundation Trust, London, EC1V 2PD

*To whom correspondence should be addressed: Dr Alan J. Stewart, Tel: +44 (0)1334 463627; E-mail: ajs21@st-andrews.ac.uk

Running title: Hydroxyapatite-binding plasma proteins in AMD

Key words: drusen, sub-retinal pigment epithelial deposits, mineral-protein interactions, retinal disease, quantitative proteomics

\begin{abstract}
Abbreviations: AMD, age-related macular degeneration; APOC4, apolipoprotein C4; BCA, bicinchoninic acid; $\mathrm{C} 4 \mathrm{~A}$, complement factor $\mathrm{C} 4 \mathrm{~A}$; $\mathrm{C} 4 \mathrm{~B}$, complement factor $\mathrm{C} 4 \mathrm{~B}$; $\mathrm{C} 8 \mathrm{~A}$, complement factor $\mathrm{C} 8 \mathrm{~A}$; C8B, complement factor C8B; $\mathrm{CFH}$, complement factor $\mathrm{H}$; ELISA, enzyme-linked immunosorbent assay; FDR, false discovery rate; FHR1, factor H-related protein 1; FHR3, factor H-related protein 3; HAP, hydroxyapatite; IC1, plasma protease C1 inhibitor; iRT, indexed retention time; PZP, pregnancy zone protein; RPE, retinal pigment epithelium; SNP, single nucleotide polymorphism; SWATH-MS, sequential window acquisition of all theoretical fragment-ion spectra by mass spectrometry.
\end{abstract}




\begin{abstract}
Age-related macular degeneration (AMD) is associated with the formation of sub-retinal pigment epithelial (RPE) deposits that block circulatory exchange with the retina. The factors that contribute to deposit formation are not well understood. Recently, we identified the presence of spherular hydroxyapatite (HAP) structures within sub-RPE deposits to which several AMD-associated proteins were bound. This suggested that protein binding to HAP represents a potential mechanism for the retention of proteins in the sub-RPE space. Here we performed quantitative proteomics using Sequential Window Acquisition of all THeoretical fragment-ion spectra-Mass Spectrometry (SWATH-MS) on plasma samples from 23 patients with late-stage neovascular AMD following HAP-binding. Individuals were genotyped for the high risk $\mathrm{CFH}$ variant (T1277C) and binding to HAP was compared between wild type and risk variants. From a library of 242 HAP binding plasma proteins (1\% false discovery rate), SWATH-MS revealed significant quantitative differences in the abundance of 32 HAPbinding proteins $(\mathrm{p}<0.05)$ between the two homozygous groups. The concentrations of six proteins (FHR1, FHR3, APOC4, C4A, C4B and PZP) in the HAP eluted fractions and whole plasma were further analysed using ELISA and their presence in sections from human cadaver eyes was examined using immunofluorescence. All six proteins were found to be present in the RPE/choroid interface, and four of these (FHR1, FHR3, APOC4 and PZP) were associated with spherules in sub-RPE space. This study provides qualitative and quantitative information relating to the degree by which plasma proteins may contribute to sub-RPE deposit formation through binding to HAP spherules and how genetic differences might contribute to deposit formation.
\end{abstract}




\section{Introduction}

Age-related macular degeneration (AMD) is the leading cause of visual impairment in the elderly in the developed world (Congdon et al., 2003). One of the hallmarks of AMD is the formation and growth of sub-retinal pigment epithelial (RPE) deposits in the macula that can be focal (drusen) or diffuse (basal linear laminar deposits; Bird et al., 2010; Sarks, 1976) There are several potential sources of accumulating proteins in the sub-RPE space. These include circulatory proteins from the vasculature and RPE secreted proteins. Curcio et al. have drawn an analogy between drusen formation in the retina and plaque formation in arterial walls (Curcio et al., 2001). It was also suggested that drusen originates primarily from incomplete digestion of photoreceptor outer segments (Farkas et al., 1971). In fact, the most likely scenario is that sub-RPE deposits originate from a range of sources, and Crabb et al. have identified constituents of drusen consistent with this (Crabb et al., 2002). It was, however, not clear how these proteins are retained in the sub-RPE space until it was demonstrated that all sub-RPE deposits appear to contain hydroxyapatite (HAP) spherules that, via their binding capacity to proteins, can serve as a retainer (Thompson et al., 2015)

Based on immunohistochemical analysis of sub-RPE deposits, it was proposed that AMD is associated with complement attack (Hageman et al., 2001). Further support for the involvement of the complement system in AMD was provided by genetic studies that identified a mutation in the complement factor $\mathrm{H}(\mathrm{CFH})$ gene that in turn increased the risk to develop AMD by several folds (Edwards et al., 2005; Haines et al. 2005; Klein et al., 2005; Toomey et al., 2015). Since then, further genetic associations between the complement system and AMD have been uncovered. However, the mechanism(s) with which CFH or its genetic polymorphisms contribute to AMD is not fully understood although information is emerging (van Asten et al., 2017).

CFH is a component of sub-RPE deposits (Klein et al., 2005), and is associated with HAP spherules (Thompson et al., 2015). It can form multimeric complexes (Perkins et al., 2012) or can undergo zinc-induced self-association with complement C3b (Nan et al., 2013), all of which directly influence the regulation of the complement cascade. As the RPE-expressed CFH appears to be preferentially secreted apically towards to the photoreceptor (Kim et al., 2009) the sub-RPE CFH could be derived from the blood circulation. As other proteins from the circulation appear to contribute to sub-RPE deposit formation (Crabb et al., 2002), it is important to define which of these could be retained in the sub-RPE space due to binding to 
HAP. Changes in plasma composition have been associated with early onset drusen formation (Kobayashi et al., 2014), it is thus important to determine whether CFH genotype affects the plasma proteome and thus the HAP interactome.

Here, we quantitatively identify HAP-binding proteins in the plasma of individuals genotyped for the most common AMD-associated CFH polymorphism (T1277C) in late-stage AMD patients by Sequential Window Acquisition of all THeoretical Mass Spectra (SWATH-MS). The concentrations of several proteins that exhibited quantitative differences in HAP eluted fractions were further examined using ELISA and their presence in RPE/choroid interface in sections from human cadaver eyes assessed using immunofluorescence. This study explores the influence of an AMD-associated CFH polymorphism on the plasma abundance of HAPbinding proteins. We believe the presented findings will be useful in determining how genetic factors may contribute to the formation of sub-RPE deposits.

\section{Materials and Methods}

\subsection{Patient information and sample collection}

Plasma samples were taken from 23 individuals aged 65-90 with late stage AMD, each displaying drusen and choroidal neovascularisation in clinical images and attending the antiVEGF injection clinic at Moorfields Eye Hospital, London. Following consent, the haematocrit values were determined before blood collection into $\mathrm{K}_{2}$ EDTA bags (Macopharma, Twickenham, UK) for plasma separation by centrifugation (10 minutes at $1300 \mathrm{RCF}$ at room temperature). The plasma was then aliquoted and frozen immediately at 80C. Red-cupped blood collection tubes were used for DNA isolation (Becton and Dickinson, Plymouth, UK). To determine the genotype of the blood samples PCR (with GoTaq DNA polymerase, Promega, Southampton, UK) and Sanger sequencing (with Big Dye v3.1; Life Technologies, Paisley, UK) was carried out according to manufacturer's instructions. The samples were run on ABI3730 DNA Sequencer. For the proteomic analysis, samples were run with technical duplicates and we included no fewer than 6 biological samples from each of the CFH genotypic groups: homozygous T1277, homozygous C1277 and heterozygous T/C1277. There was no statistically significant difference in age between the participants assigned to each of the three genotypic groups (one-way ANOVA; Kruskal-Wallis test, p=0.1373). The study was approved by Bromley Local Research Ethics Committee (REC reference number: 08/H0805/6) and adhered to the conventions of the Helsinki Declaration. 


\subsection{Sample preparation for mass spectroscopy}

Plasma samples were filtered using $0.45 \mu \mathrm{m}$ syringe filter (precautionary stto remove particles that could block the columns) and depleted of albumin and IgG with single-use spin columns using the Albumin and IgG Depletion SpinTrap kit (GE Healthcare, Buckinghamshire, UK The resulting plasma was quantitated using BCA/bicinchoninic acid assay (Thermo Fisher Scientific, Paisley, UK) and $600 \mu \mathrm{g}$ of plasma proteins from each sample werebound to $10 \mathrm{mg}$ of CHT ceramic HAP type-I beads (Bio-Rad, Hertfordshire, UK), in individual microcentrifuge tubes The HAP beads were used once (and not recycled) in order to avoid any cross-contamination. These spherical beads are coated with HAP at their surface providing a similar structure and chemical surface to that present in vivo in the human eye (Thompson et al., 2015). They therefore represent an ideal medium for the in vitro identification of HAP binding proteins. Plasma protein binding was carried out in a binding buffer composed of $10 \mathrm{mM}$ sodium phosphate, $75 \mathrm{mM}$ sodium chloride, $\mathrm{pH}$ 7.4. Bound proteins were eluted in $250 \mathrm{mM}$ sodium phosphate, $10 \mathrm{mM}$ Tris- $\mathrm{Cl}, 0.5 \mathrm{M}$ sodium chloride, $\mathrm{pH}$ 7.4. The resulting proteins were quantified using a bicinchoninic acid assay.

All samples for mass spectrometric analysis were processed as follows: Samples containing $30 \mu \mathrm{g}$ of protein were denatured in $6 \mathrm{M}$ urea in $50 \mathrm{mM}$ ammonium bicarbonate and were then reduced and alkylated with $1 \mathrm{mM}$ tris (2-carboxyethyl) phosphine and $5 \mathrm{mM}$ iodoacetamide. The reaction was quenched with $10 \mathrm{mM}$ dithiothreitol. Samples were diluted with $50 \mathrm{mM}$ ammonium bicarbonate to a final urea concentration of $1.5 \mathrm{M}$. The resulting samples were then digested with trypsin (1:50 ratio (w/w), $0.2 \mu \mathrm{g} / \mu \mathrm{l}$ trypsin; Promega, Southampton, UK), overnight at $30^{\circ} \mathrm{C}$. The digestion was stopped upon addition of $0.5 \%(\mathrm{v} / \mathrm{v})$ trifluoroacetic acid. Peptides were desalted using a C18 SepPak cartridge (Thermo Fisher Scientific) and dried under vacuum.

\subsection{Protein identification after HAP binding by LC-ESI-MSMS}

Albumin/IgG-depleted plasma proteins were analysed after HAP binding. For this, $1 \mu \mathrm{g}$ of the respective sample peptides were injected on an AB Sciex TripleTOF 5600+ system mass spectrometer (Sciex, Framingham, MA, USA) coupled to an Eksigent nanoLC AS-2/2Dplus system (Sciex). Prior to mass spectrometric analysis, iRT reference peptides (Biognosys, Schlieren, Switzerland) were added to each sample according to the manufacturer's 
specifications. The samples were prepared in loading buffer (2\% acetonitrile, $0.05 \%$ trifluoroacetic acid), bound to an Acclaim Pepmap $100 \mu \mathrm{m} \times 2 \mathrm{~cm}$ trap (Thermo Fisher Scientific) and washed for $10 \mathrm{~min}$ to waste after which the trap was turned in-line with the analytical column (Acclaim Pepmap RSLC $75 \mu \mathrm{m} \times 15 \mathrm{~cm}$ ). The analytical solvent system consisted of buffer A ( $2 \%$ acetonitrile, $0.1 \%$ formic acid in water) and buffer B ( $2 \%$ water, $0.1 \%$ formic acid in acetonitrile) at a flow rate of $0.3 \mu \mathrm{l} / \mathrm{min}$ with the following gradient: linear 1-20\% of buffer B over 90 min, linear $20-40 \%$ of buffer B for $30 \mathrm{~min}$, linear $40-99 \%$ of buffer B for $10 \mathrm{~min}$, isocratic $99 \%$ of buffer B for $5 \mathrm{~min}$, linear $99-1 \%$ of buffer B for $2.5 \mathrm{~min}$ and isocratic 1\% solvent buffer B for $12.5 \mathrm{~min}$. The mass spectrometer was operated in DDA top 20 positive ion mode, with 250 and $150 \mathrm{~ms}$ acquisition time for the MS1 (m/z 400-1200) and MS2 (m/z 230-1800) scans respectively, and 15 s dynamic exclusion. Rolling collision energy with a collision energy spread of $5 \mathrm{eV}$ was used for fragmentation. The data files were searched using Protein Pilot v5.0.1 (Sciex) with the following search parameters: urea denaturation as special factors, trypsin as the cleavage enzyme and carbamidomethylation as a fixed modification of cysteines. The search was carried out in "rapid ID" mode with a detected protein threshold of $10 \%$ plus false discovery rate analysis against the Swissprot database downloaded June 2015, restricted only to proteins from humans. Note that the iRT peptides were added to this database.

2.4. Sequential window acquisition of all theoretical fragment-ion spectra-mass spectrometry (SWATH-MS)

\subsubsection{LC-ESI-MS/MS analysis for spectral library generation}

For spectral library generation, $1 \mu \mathrm{g}$ of peptides from each individually digested HAP eluate sample from each patient were combined to be a representative sample. This sample was analysed on an AB Sciex TripleTOF 5600+ system mass spectrometer coupled to an Eksigent nanoLC AS-2/2Dplus system as described in Section 2.3. The data was searched against three databases resulting in three different libraries. The first was the original Swissprot database (downloaded June 2015), restricted only to proteins from humans. This database contains FHR1 in its original form (with the amino acid sequence, STDTSCVNPPTVQNAHILSR at position 142 to 161; FHR1a). The second database is identical to this original Swissprot database but contains FHR1b instead of FHR1a (with the amino acid sequence, STDTSCVNPPTVQNAYIVSR at position 142 to 161). The third database was the original Swissprot database but the C-terminus but the protein sequence for FHR1a was extended to 
include the following sequence: STDTSCVNPPTVQNAYIVSR (taken from FHR1b). The sequences of the iRT peptides were added to each database.

\subsubsection{SWATH-MS data acquisition and analysis}

For SWATH-MS data acquisition, the same mass spectrometer and LC-MS/MS setup as described above was used, but operated in SWATH mode. The method uses 50 windows of variable Da effective isolation width with a 1 Da overlap using AB Sciex Variable Window Calculator tool. Each window has a dwell time of $150 \mathrm{~ms}$ to cover the mass range of 400$1250 \mathrm{~m} / \mathrm{z}$ in TOF-MS mode and MS/MS data is acquired over a range of $230-1800 \mathrm{~m} / \mathrm{z}$ with high sensitivity setting and a dwell time of $70 \mathrm{~ms}$, resulting in a cycle time of $3.6 \mathrm{~s}$. The collision energy for each window was set using the collision energy of a $2^{+}$ion centred in the middle of the window with a spread of $5 \mathrm{eV}$. During data processing identified proteins with a $1 \%$ false detection rate (FDR) at the global protein level (242 proteins) were imported into PeakView 2.2 (Sciex) for spectral library generation. SWATH-MS results were analysed using SWATH micro App (v2.0) embedded in PeakView. Sample peptide retention times were calibrated against the iRT peptide retention times. The data was then further processed with the following settings: 10 peptides/protein, 5 transitions/peptide, peptide confidence threshold of $95 \%$, FDR threshold of $1 \%$. Modified and shared peptides were excluded. The XIC extraction window was set to $6 \mathrm{~min}$ and $10 \mathrm{ppm}$. The quantified protein peak areas were then exported into Markerview 1.2.1.1 (Sciex) for data normalisation. Relative protein quantitation and statistical tests were performed using Microsoft Excel. Basic statistical calculations were performed using Markerview software. The p-values were calculated using students t-test and the q-values were calculated using the Benjamini Hochberg method. The mass spectrometry proteomics data is available at the ProteomeXchange Consortium, PRIDE with the dataset identifier PXD007944.

\subsection{STRING analysis}

The protein interaction network for significantly changing HAP binding plasma proteins (between the homozygous CFH genotyped groups) was analysed by STRING software (https://string-db.org/). As a reference dataset we used the human plasma proteome from the Plasma Proteome Database's official website (http://plasmaproteomedatabase.org/).

\subsection{Enzyme-linked immunosorbent assays (ELISAs)}


ELISAs were performed on patient plasma prior to and following HAP bead binding and elution. Patient plasma was filtered through $0.45 \mu \mathrm{m}$ filter and incubated with and eluted from $10 \mathrm{mg}$ of CHT ceramic HAP beads as described above for SWATH-MS preparation. The ELISAs were performed using commercially available kits (all from Cloud-Clone Corp., Buckingham, UK) for pregnancy zone protein (PZP, \#SEG324Hu), complement factor $\mathrm{H}$ related protein 1(FHR1, \#SEL327HU), complement factor H-related protein 3 (FHR3, \# SEL329Hu), apolipoprotein C4 (APOC4, \#SEB828Hu), complement factor 4A (C4A, \#SEA389Hu) and complement factor 4B (C4B, \#SEB305Hu) in accordance with the manufacturer's instructions. Statistical comparisons (p-values) were done by one-way ANOVA using Dunnet's multiple comparison test.

\subsection{Immunofluorescence imaging}

Tissues were obtained from the Eye Depository at the UCL Institute of Ophthalmology, London. Approval for the use of these tissues was obtained from the UCL Institute of Ophthalmology Local Research Ethics Committee (REC reference number: 10/H0106/572012ETR26). The donor eyes were fixed <24 hours after death. Samples were selected based on the presence of drusen from male and female donors, aged between 76 and 94 years, without clinical and genotype information. Four micron sections containing several drusen were selected after microscopic evaluation of formalin-fixed paraffin embedded tissues following hematoxilin-eosin staining. In addition, adjacent sections were labelled with von Kossa (Puchtler and Meloen, 1978) and OsteoSense 680EX (Figueiredo et al., 2008) to verify the presence of mineral in the deposits.

Antigen retrieval was carried out in $10 \mathrm{mM}$ citrate buffer $(\mathrm{pH} \mathrm{6)}$. The sections were heated for $9 \mathrm{~min}$ in a microwave following de-paraffinisation. The samples were blocked with $20 \%$ goat sera for $1 \mathrm{hr}$ at room temperature. Afterwards, the sections from 3-5 donors were incubated with primary antibodies overnight at $4^{\circ} \mathrm{C}$; C4A (ab170942, Abcam, Cambridge, UK, 1:50 dilution); C4B (ab181241, Abcam, 1:250 dilution); FHR1 (ab182652, Abcam, 1:50 dilution); APOC4 (ab199163, Abcam, 1:50 dilution); PZP (Abcam: ab122718, 1:20 dilution); FHR3 (16583-1-AP, Proteintech, Manchester, UK, 1:100 dilution); amyloid- $\beta$ 1-16 (SIG39320, Covance, London, UK, 1:100) followed by incubation with goat anti-rabbit or goat anti-mouse secondary antibody conjugated to alexa-fluor 488 or 568 , respectively (Life Technologies, Paisley, UK), at 1:200 dilution for $1 \mathrm{hr}$ at room temperature. Slides were counterstained for nuclei with DAPI (Thermo Fisher Scientific, 1:1000 dilution) for 15 min at 
room temperature and mounted with antifade mounting media (Vector Laboratories, Peterborough, UK) using glass coverslips (Thermo Fisher Scientific). Optical sections were generated using a Leica TCS SP8 confocal laser scanning microscope (Leica Microsystems, Milton Keynes, UK). The images presented are in all cases representative.

\section{Results}

3.1. Quantitative analysis of HAP-binding plasma proteins in individuals with late-stage $A M D$

For SWATH-MS quantitation, a sample specific reference spectral library was generated (for use as a reference in generating peptide query parameters for the peptide centric analysis of the data) by data-dependent acquisition analysis of the HAP-binding plasma proteins. This resulted in a spectral library consisting of 242 human plasma proteins with a FDR of $1 \%$ on the protein level. To determine the differences in levels of HAP-binding proteins present across the different $\mathrm{CFH}$ genotypic groups, we measured quantitative proteome profiles of HAP-eluted plasma proteins in each individual sample by SWATH-MS. Comparisons of the obtained quantitative data identified 210 proteins (1\% FDR) that were consistently detected in all samples. The quantitative information for the 174 proteins that were quantified based on 2 or more peptides is provided in Table S2. To account for the probability of minor sample variability due to multiple steps in sample processing, all the samples were prepared in duplicates and ran as technical replicates. A principal component analysis of the proteomic data obtained from individual samples $(\mathrm{PC} 1=13.6 \%, \mathrm{PC} 2=7.9 \%)$ revealed that the samples did not vary greatly as a collective, with technical replicates clustering together closely (indicating strong reproducibility) as shown in Figure S1. A volcano plot showing a comparison of relative abundance of all HAP-binding plasma proteins between T/T1277 and C/C1277 groups is presented in Figure 1A. Of the proteins consistently quantified, the relative abundance of a total of 32 unique proteins (14\%) was statistically significantly altered (p-value $\leq 0.05$ ) between T/T1277 and C/C1277 groups. Multiple hypothesis testing was also performed with the respective q-values calculated. However, these were too stringent for this study and as such were not used in determining significance. An analysis of the STRING database for these 32 proteins (shown in Figure 1B) indicates that they have more interactions among themselves than would be expected for a random set of 32 proteins drawn from the proteome. Such enrichment indicates that the proteins might be, at least partially, biologically connected as a group. The quantitative data for all significantly altered proteins is presented in Figure 1C. 
Twenty-one plasma proteins were found to exhibit a statistically significant increase $(p \leq 0.05)$ in mean relative abundance (represented as average peak intensity in Table S2) in the C/C1277 group (compared to the T/T1277 group). Of those displaying the greatest increase were IgG delta chain $\mathrm{C}$ region ( 2.8 -fold change; $\mathrm{p}=0.04)$, thrombospondin-I ( 2.2-fold change; $\mathrm{p}=0.0342)$, FHR1 $\left(\sim 2.1\right.$-fold change; $\left.\mathrm{p}=6.58 \times 10^{-8}\right)$, platelet basic protein $(\sim 2$-fold change; $\mathrm{p}=0.04)$. The observed increased abundance of FHR1 protein in the $\mathrm{C} / \mathrm{C} 1277$ group was interesting as a variant (FHR1a) of the corresponding gene is associated with AMD, and is genetically linked to the C1277 CFH allele (Timmann et al., 1991; Martínez-Barricarte et $a l .$, 2012). FHR1a encodes a protein, which is the same length as (the other variant) FHR1b but differs in amino acid sequence at 3 residues (H157Y, L159V and E175Q). Examination of FHR1-derived peptides in the SWATH-MS spectra revealed that FHR1a and FHR1b variants could be identified within the samples based upon the presence of a peptide unique to each form. This was achieved by generating separate peptide libraries containing peptides derived from either FHR1a or FHR1b variant proteins. The presence of FHR1a and FHR1b variants within the $\mathrm{C} / \mathrm{C} 1277$ and T/T1277 groups were analysed by quantitative mass spectrometric analysis as shown in Figure 2. The p-values were calculated by one-way ANOVA using Dunnet's multiple comparison test. The results confirmed strong associations between the C1277 CFH allele and FHR1a and the T1277 and FHR1b, respectively.

Eleven plasma proteins found to exhibit a statistically significant increase $(p \leq 0.05)$ in mean relative abundance in the T/T1277 group (compared to the $\mathrm{C} / \mathrm{C} 1277$ group). Of those displaying the greatest increase were PZP ( 2-fold change; p=0.01), APOC4 ( 1.7-fold change; $\mathrm{p}=0.0118)$, FHR3 ( 1.7-fold change; $\mathrm{p}=0.001)$, C4B ( 1.7-fold change; $\mathrm{p}=0.01)$, vitamin K-dependent protein $\mathrm{Z}(\sim 1.6$-fold change; $\mathrm{p}=0.03)$ and $\mathrm{C} 4 \mathrm{~A}(\sim 1.6$-fold change; $\mathrm{p}=0.01$ ). Although PZP exhibited the greatest increase in mean relative abundance in the T/T1277 group, the protein has been shown previously to be expressed at higher levels in females when compared to levels in males (Folkersen et al., 1981). To determine whether this observation may have been due to sex differences in individuals within the groups, we carried out a separate analysis of the SWATH-MS data where samples from females were compared with those from males (as shown in Table S3). This analysis suggested that PZP may only be increased in the T/T1277 group as it is more prevalent in females as there was a bias toward females in this genetic group in our study. The abundance of six other proteins (protein S100A9, Ig alpha-2 chain $\mathrm{C}$ region, cystatin $\mathrm{C}$, Ig kappa chain V-III region POM, complement 
factor D and carboxypeptidase B2) was also found to significantly differ between male and female participants (in all these cases levels were higher in males) but did not vary significantly across the three $\mathrm{CFH}$ genotypic groups.

\subsection{Determination of concentrations of plasma proteins exhibiting quantitative differences} between genotypic groups

Several proteins that exhibited differing mean relative abundances in the different $\mathrm{CFH}$ genotypic groups were chosen for further analysis - these were PZP, FHR1, FHR3, APOC4, $\mathrm{C} 4 \mathrm{~A}$ and $\mathrm{C} 4 \mathrm{~B}$. Although APOC4 was quantified based on single peptide we thought it also merited further analysis given that it displayed a statistically significant p-value (0.01) and relatively high fold-change (1.7), in the T/T1277 vs C/C1277 comparison and a confident signal in SWATH-MS. To validate the findings from the SWATH-MS analysis and to determine whether differences in relative abundance of these proteins between samples from different genotypic groups were due to affinity/competition effects of HAP-binding or their plasma concentration prior to binding, ELISA assays were carried out both on untreated plasma samples and the HAP-eluted samples subjected to the SWATH-MS analysis. The resultant data is shown in Figure 3. Statistically significant differences in the concentrations of each of the six proteins were observed in both the native plasma and processed samples, suggesting that the differences in abundance of these proteins between groups were most likely due to initial differences in the plasma concentrations of these proteins prior to processing.

\subsection{Immunohistochemistry of identified plasma proteins in cadaveric retinal tissue}

Human cadaveric eye sections pre-screened according to Thompson et al. (2015) contained several drusen and HAP spherules were immunolabelled for the detection of C4A, C4B, APOC4, PZP, FHR3 and FHR1 (Figure 4). For visualisation of HAP spherules, we used amyloid- $\beta$ immunolabelling as the acidity of the citrate buffer used for antigen retrieval inhibited HAP labelling. The amyloid- $\beta$ antibody 6 E10 reliably co-localises with some of the HAP spherules (Dentchev et al., 2003; Anderson et al., 2004; Luibl et al., 2006; Thompson et al., 2015). FHR1, FHR3, PZP and APOC4 showed distinct spheroid shape immunostaining that co-localised with amyloid- $\beta$ (Figure 4A-F). C4A and C4B immunolabelling was localised in most cases to choriocapillary pillars (Figure 4G-I). Complement C4A was also observed in drusen, but did not appear in association with amyloid- $\beta$ (Fig 4G). APOC4, PZP and FHR3 were also detected in RPE cells (Figure 4B-F) and FHR1 and PZP were present in 
the Bruch's membrane (Figure 4A and E). In addition, FHR1 immunolabelling was observed in the choriocapillary pillars (Figure 4A).

\section{Discussion}

Several reports have described circulatory plasma biomarkers for AMD (Gu et al., 2010; Lambert et al., 2016; Kersten et al., 2017). However, how these contribute to the development and progression of the AMD is not well understood. Plasma proteins appear to contribute to the development and growth of sub-RPE deposits (Crabb et al., 2002) and as sub-RPE deposit accumulation is a hallmark of AMD (Bird, 2003), understanding how plasma proteins may contribute to deposit formation could be important to identify early events in AMD pathogenesis. In this study, we examined the relationship between genotype and abundance of HAP-binding plasma proteins that are potentially involved in deposit formation. We made two new and significant observations: 1) at least 242 plasma proteins can readily bind HAP (either directly or, in some cases, via association with another HAPbinding protein); 2) genetic variations in $\mathrm{CFH}$ can influence the plasma concentration of some of these proteins.

In our SWATH-MS analysis $14 \%$ of quantified plasma proteins showed statistically significant difference when CFH genotyped samples (T/T1277 and C/C1277) were compared (32 out of 242). A STRING analysis of the 32 proteins revealed that many of these proteins are biologically connected: for example, we found 8 complement or complement-related proteins as well as 2 apolipoproteins (APOC4 was not included) amongst these proteins. Such connections might be relevant because they align with the concept that complement dysregulation and changes in lipid homeostasis are mechanistically involved in AMD pathogenesis. In addition, protein-protein interactions could lead to the growth of sub-RPE deposits.

The HAP-binding protein exhibiting the most significant relative decrease in samples from the T/T1277 compared to C/C1277 group, was FHR1 (fold-change of 0.47; p-value $\geq 6.58 \times 10^{-8}$ ). An ELISA-based analysis confirmed this finding in both whole plasma samples and those eluted from HAP beads. FHR1 is a CFH-related protein that exists in two polymorphic forms, FHR1a and FHR1b derived from distinct FHR1 alleles. Further inspection of the SWATH-MS data revealed that a peptide specific to the FHR1a form was found in all samples derived from $\mathrm{C} / \mathrm{C} 1277$ subjects and absent in all but one sample derived 
from the T/T1277 subjects. Similarly, a peptide specific to the FHR1b protein was found in all T/T1277 derived samples and absent in all but one sample derived from the C/C1277 subjects. This is the first time that such an association has been shown at the protein level, supporting a previous study suggesting a link between the corresponding $\mathrm{CFH}$ and FHR1 genotypes (Martinez-Barricante et al., 2012). Interestingly, deletion of the gene encoding FHR1 together with FHR3, which we conversely found to be more abundant in the T/T1277 subjects, is associated with a reduced risk of developing AMD. The specific role(s) these proteins play in the aetiology of AMD is unclear, but it is thought that they may function to modulate CFH activity in vivo (Fritsche et al., 2010). In addition, our study demonstrates that both FHR1 and FHR3 could bind to HAP and associate with spherules at the RPE/choroid interface.

In our analysis of the HAP-eluted plasma proteins, significantly higher plasma levels of both C4A and C4B (1.68 and 1.57-fold, respectively) were observed in individuals with the T/T1277 CFH genotype than those with the C/C1277 genotype, with this trend confirmed by ELISA both after HAP-binding and in whole plasma. This is an interesting finding as it suggests that an allelic difference in $\mathrm{CFH}$, which encodes a protein associated with the alternative complement pathway, influences the plasma level of $\mathrm{C} 4$, which is essentially a classical pathway component. In eye sections both $\mathrm{C} 4 \mathrm{~A}$ and $\mathrm{C} 4 \mathrm{~B}$ were found to be present in the choriocapilliary pillars in every section we examined, and C4A occasionally associated with drusen but neither were observed to be associated with HAP spherules in the sections we examined. Examining further sections may clarify whether HAP-association exists. In a previous quantitative proteomics analysis of Bruch's membrane/choroid complex from patients with $\mathrm{AMD}$, it was revealed that $\mathrm{C} 4 \mathrm{~A}$ and $\mathrm{C} 4 \mathrm{~B}$ are present in this complex and that C4A was statistically significantly more prevalent in the AMD group compared to controls (Yuan et al., 2010).

Another protein that exhibited higher plasma levels in T/T1277 individuals was plasma protease $\mathrm{C} 1$ inhibitor (IC1; 1.4-fold), a negative regulator of the classical pathway. IC1 is a glycoprotein inhibitor of activated complement factor $1 \mathrm{r}$ and $1 \mathrm{~s}$ proteins, which form part of the first complement component (C1). Deficiency of IC1 is associated with hereditary angioneurotic oedema (Cugno et al., 2009). It is possible that the relatively lower abundance of either IC1 or $\mathrm{C} 4$ proteins (in $\mathrm{C} / \mathrm{C} 1277$ group relative to $\mathrm{T} / \mathrm{T} 1277$ group) could be interdependent and that the change in concentration of either occurs to maintain balance of 
the classical pathway. Other components of the complement cascade, C8 (both C8A and C8B proteins) and complement factor I (negative regulator of alternative pathway), were also found to be higher in the T/T1277 group, albeit by less than 1.3-fold. We hasten to add that though these results are interesting and may have functional implications, it is not possible based on this data alone to relate these observations directly to complement dysregulation in AMD

Defective lipid metabolism and genotypic differences in genes encoding proteins involved in lipid transport have also been associated with the risk of developing AMD (Cheung et al., 2017). Such genes include those encoding apolipoproteins such as ApoE and ApoB (Klaver et al., 1998, Baird et al., 2006, Curcio et al., 2010). In our SWATH-MS analysis we observed a higher abundance of APOC4 and ApoE in the HAP-eluted protein fractions derived from the T/T1277 group, relative to the $\mathrm{C} / \mathrm{C} 1277$ group (1.78-fold and 1.24-fold, respectively). The difference in APOC4 levels (in the HAP-eluted fractions) between T/T1277 and C/C1277 groups were also confirmed by ELISA, with levels of APOC4 in whole plasma also being significantly higher in the T/T1277 group. In retinal sections APOC4 was found to colocalise with spherular structures and was also found to be expressed in RPE cells. Associations between APOC4 and AMD have been reported previously based on genomewide candidate gene association studies (Pennington and DeAngelis, 2016). It is therefore possible that this protein may be involved in AMD pathogenesis by binding to HAP in the sub-RPE space.

We also identified new sub-RPE deposit-associated proteins that might be relevant for AMD progression. The protein that exhibited the greatest increase in relative abundance in the T/T1277 group compared to the C/C1277 group was PZP, an $\alpha 2$-macroglobulin-like endopeptidase inhibitory protein recently implicated in Alzheimer's disease and identified within amyloid plaques in cadaveric brain tissue (Ijsselstijn et al., 2011; Nijholt et al., 2015). However, PZP was found to be higher in samples taken from females rather than males, which could account for this difference (as the T/T1277 group consisted exclusively of female subjects), although it should be noted that females are more predisposed to developing AMD than males (Owen et al., 2012; Rudnicka et al., 2012). PZP has not previously been associated with sub-RPE deposit formation or AMD. Here we found that the protein is present in drusen and associated with spherular structures. PZP was also present in the Bruch's membrane and in the RPE. These observations support the hypothesis that PZP may 
contribute to the growth of deposits, thickening of Bruch's membrane and thus the progression of AMD.

A number of proteins present in plasma, including complement factors, have already been identified in drusen (Crabb et al., 2002; Hollyfield et al., 2003), with some of these, such as haemoglobin, specific to the blood (Crabb et al., 2002; Beattie et al., 2010). These data together with our findings collectively suggest that plasma proteins are likely to contribute to sub-RPE deposit formation. The differences in concentrations of potential deposit-forming plasma proteins in AMD-affected individuals of different genotypes could points towards different aetiologies of disease. For example, based on our data, FHR1 may play a more prominent role in sub-RPE deposit formation in individuals with the $\mathrm{C} / \mathrm{C} 1277 \mathrm{CFH}$ genotype than those with the T/T1277 genotype.

In conclusion, this study has utilised a new quantitative proteomic approach to understand the potential molecular events that give rise to sub-RPE deposit formation, a feature central to the development of AMD. More specifically, we have identified a number of a plasma proteins that can bind HAP and are differentially expressed in plasmas from individuals belonging to different genotypic groups. These observations point towards different aetiologies of subRPE deposit formation and heterogeneity and why people from different genetic backgrounds develop AMD. Given that the retention of proteins in the sub-RPE space occurs at a very early stage of the disease process, targeting the binding of key proteins to HAP may provide a robust therapeutic strategy that could slow or even prevent drusen formation.

\section{Contributors}

Study concept and design: S.A., E.E., C.H.B., I.L., A.J.S.; collection of blood samples: N.B.B., T.P.; acquisition of data: S.A., E.E., S.A.S., S.L.S.; analysis and interpretation of data: S.A., E.E., S.A.S., C.H.B., I.L., A.J.S.; drafting of the manuscript: S.A., E.E., S.A.S., I.L., A.J.S.; and all authors critically reviewed the manuscript and approved the final version.

\section{Competing Interests}

The authors have no competing interests to declare.

\section{Acknowledgements}


The investigators would like to thank the patients for their donation of blood samples for the study. Yash Bansod and Lasse Olesen are acknowledged for their technical help with the immunohistochemistry examination. We are also grateful to Fight for Sight for financial support (project grant to A.J.S and I.L.; grant ref.: 1586/1587). This research was also supported by "Eye-Risk" a European Union's Horizon 2020 research and innovation program (grant ref.: 634479) Bill Brown Charitable Trust, MEH Special Trustees and Mercer Fund (I.L). This work was also supported by the Wellcome Trust (grant ref.: 094476/Z/10/Z) for funding the purchase of the TripleTOF 5600 mass spectrometer at the BSRC Mass Spectrometry and Proteomics Facility, University of St Andrews.

\section{References}

Anderson, D.H., Talaga, K.C., Rivest, A.J., Barron, E., Hageman, G., Johnson, L.V., 2004. Characterization of $\beta$ amyloid assemblies in drusen: the deposits associated with aging and age-related macular degeneration. Exp. Eye Res. 78, 243-256.

Baird, P.N., Richardson, A.J., Robman, L.D., Dimitrov, P.N., Tikellis, G., McCarty, C.A., Guymer, R.H., 2006. Apolipoprotein (APOE) gene is associated with progression of age-related macular degeneration (AMD). Hum. Mutat. 27, 337-342.

Beattie, J.R., Pawlak, A.M., Boulton, M.E., Zhang, J., Monnier, V.M, McGarvey, J.J., Stitt, A.W., 2010. Multiplex analysis of age-related protein and lipid modifications in human Bruch's membrane. FASEB J. 24, 4816-4824.

Bird, A.C., 2003. The Bowman lecture. Towards an understanding of age-related macular disease. Eye 17, 457-466.

Bird, A.C., 2010. Therapeutic targets in age-related macular disease. J. Clin. Invest. 120, 3033-3041.

Cheung, C.M.G., Gan, A., Fan, Q., Chee, M.L., Apte, R.S., Khor, C.C., Yeo, I., Mathur, R., Cheng, C.Y., Wong, T.Y., 2017. Plasma lipoprotein subfraction concentrations are associated with lipid metabolism and age-related macular degeneration. J. Lipid Res. 58, 1785-1796.

Congdon, N.G., Friedman, D.S. and Lietman, T., 2003. Important causes of visual impairment in the world today. JAMA 290, 2057-2060

Crabb, J.W., Miyagi, M., Gu, X., Shadrach, K., West, K.A., Sakaguchi, H., Kamei, M., Hasan, A., Yan, L., Rayborn, M.E., Salomon, R.G., Hollyfield, J.G., 2002. Drusen proteome analysis: an approach to the etiology of age-related macular degeneration. Proc. Natl. Acad. Sci. USA. 99, 14682-14687. 
Cugno, M., Zanichelli, A., Foieni, F., Caccia, S., Cicardi, M., 2009. C1-inhibitor deficiency and angioedema: molecular mechanisms and clinical progress. Trends Mol. Med. 15, 69-78.

Curcio, C.A., Johnson, M., Huang, J.D., Rudolf, M., 2010. Apolipoprotein B-containing lipoproteins in retinal aging and age-related macular degeneration. J. Lipid Res. 51, 451-467.

Curcio, C.A., Millican, C.L., Bailey, T., Kruth, H.S., 2001. Accumulation of cholesterol with age in human Bruch's membrane. Invest. Ophthalmol. Vis. Sci. 42, 265-274.

Dentchev, T., Milam, A.H., Lee, V.M., Trojanowski, J.Q., Dunaief, J.L., 2003. Amyloid-beta is found in drusen from some age-related macular degeneration retinas, but not in drusen from normal retinas. Mol. Vis. 9, 184-190.

Edwards, O.A., Ritter, R., Abel, K.J., Manning, A., Panhuysen, C., Farrer, L.A., 2005. Complement factor $\mathrm{H}$ polymorphism and age-related macular degeneration. Science $308,421-424$.

Farkas, T.G., Sylvester, V., Archer, D., 1971. The ultrastructure of drusen. Am. J. Ophthalmol. 71, 1196-1205.

Figueiredo, J.L., Passerotti, C.C., Sponholtz, T., Nguyen, H.T., Weissleder R., 2008. A novel method of imaging calcium urolithiasis using fluorescence. J. Urol. 179, 1610-1614.

Folkersen, J., Teisner, B., Grunnet, N., Grudzinskas, J.G., Westergaard, J.G., Hindersson, P., 1981. Circulating levels of pregnancy zone protein: normal range and the influence of age and gender. Clin. Chim. Acta. 110, 139-145.

Fritsche, L.G., Lauer, N., Hartmann, A., Stippa, S., Keilhauer, C.N., Oppermann, M., Pandey, M.K., Köhl, J., Zipfel, P.F., Weber, B.H., Skerka, C., 2010. An imbalance of human complement regulatory proteins CFHR1, CFHR3 and factor $\mathrm{H}$ influences risk for agerelated macular degeneration (AMD). Hum. Mol. Genet. 19, 4694-4704.

Gu, J., Pauer, G.J., Yue, X., Narendra, U., Sturgill, G.M., Bena, J., Gu, X., Peachey, N.S., Salomon, R.G., Hagstrom, S.A., Crabb, J.W., Clinical Genomic and Proteomic AMD Study Group., 2010. Proteomic and genomic biomarkers for age-related macular degeneration. Adv. Exp. Med. Biol. 664, 411-417.

Hageman, G.S., Luthert, P.J., Victor, C.N.H., Johnson, L.V., Anderson, D.H., Mullins, R.F., 2001. An integrated hypothesis that considers drusen as biomarkers of Immunemediated processes at the RPE-Bruch's membrane interface in aging and age related macular degeneration. Prog. Retin. Eye Res. 20, 705-732. 
Haines, J.L., Hauser, M.A., Schmidt, S., Scott, W.K., Olson, L.M., Gallins, P., Spencer, K.L., Kwan, S.Y., Noureddine, M., Gilbert, J.R., Schnetz-Boutaud, N., Agarwal, A., Postel, E.A., Pericak-Vance, M.A., 2005. Complement factor $\mathrm{H}$ variant increases the risk of age-related macular degeneration. Science 308, 419-421

Hollyfield, J.G., Salomon, R.G., Crabb, J.W., 2003. Proteomic approaches to understanding age-related macular degeneration. Adv. Exp. Med. Biol. 533, 83-89.

Ijsselstijn, L., Dekker, L.J., Stingl, C., van der Weiden, M.M., Hofman. A., Kros, J.M., Koudstaal, P.J., Sillevis Smitt, P.A., Ikram, M.A., Breteler, M.M., Luider, T.M., 2011. Serum levels of pregnancy zone protein are elevated in presymptomatic Alzheimer's disease. J. Proteome Res. 10, 4902-4910.

Kersten, E., Paun, C.C., Schellevis, R.L., Hoyng, C.B., Delcourt, C., Lengyel, I., Peto, T., Ueffing, M., Klaver, C.C.W., Dammeier, S., den Hollander, A., de Jong, E.K., 2017. Systemic and ocular fluid compounds as potential biomarkers in age-related macular degeneration. Surv. Ophthalmol. 6257, 30262-30264.

Kim, Y.H., He, S., Kase, S., Kitamura, M., Ryan, S.J., Hinton, D.R., 2009. Regulated secretion of complement factor $\mathrm{H}$ by RPE and its role in RPE migration. Graefes Arch. Clin. Exp. Ophthalmol. 247, 651-659.

Klaver, C.C., Kliffen, M., van Duijn, C.M., Hofman, A., Cruts, M., Grobbee, D.E., van Broeckhoven, C., de Jong, P.T., 1998. Genetic association of apolipoprotein E with age-related macular degeneration. Am. J. Hum. Genet. 63, 200-206.

Klein, R.J., Zeiss, C., Chew, E.Y., Tsai, J.Y., Sackler, R.S., Haynes, C., Henning, A. K., SanGiovanni, P., Mane, S.M., Mayne, S.T., Bracken, M.B., Ferris, F.L., Ott, J., Barnstable, C., Hoh, J., 2005. Complement factor H polymorphism in age-related macular degeneration. Science 308, 385-389.

Kobayashi, H., Okamoto, H., Murakami, A., Iwata, T., 2014. Plasma proteome analysis on cynomolgus monkey (Macaca fascicularis) pedigrees with early onset drusen formation. Exp. Anim. 63, 305-310.

Lambert, N.G., El Shelmani, H., Singh, M.K., Mansergh, F.C., Wride, M.A., Padilla, M., Keegan, D., Hogg, R.E., Ambati, B.K., 2016. Risk factors and biomarkers of agerelated macular degeneration. Prog. Retin. Eye Res. 54, 64-102.

Luibl, V., Isas, J.M., Kayed, R., Glabe, C.G., Langen, R., Chen, J., 2006. Drusen deposits associated with aging and age-related macular degeneration contain nonfibrillar amyloid oligomers. J. Clin. Invest. 116, 378-385. 
Martínez-Barricarte, R., Recalde, S., Fernández-Robredo, P., Olavarrieta, I.M., Viñuela, A., Pérez-Pérez, J., Layana, A.G., Rodríguez de Córdoba, S., Spanish Multicenter Group on AMD, 2012. Relevance of complement factor H-related 1 (CFHR1) genotypes in age-related macular degeneration. Invest. Ophthalmol. Vis. Sci. 53, 1087-1094.

Nan, R., Tetchner, S., Rodriguez, E., Pao, P.J., Gor, J., Lengyel, I., Perkins, S.J., 2013. Zincinduced self-association of complement $\mathrm{C} 3 \mathrm{~b}$ and factor $\mathrm{H}$ : implications for inflammation and age-related macular degeneration. J. Biol. Chem. 288, 19197-19210.

Nijholt, D.A., Ijsselstijn, L., van der Weiden, M.M., Zheng, P.P., Sillevis, Smitt, P.A., Koudstaal, P.J., Luider, T.M., Kros, J.M., 2015. Pregnancy zone protein is increased in the Alzheimer's disease brain and associates with senile plaques. J. Alzheimers Dis. 46, 227-238.

Owen, C.G., Jarrar, Z., Wormald, R., Cook, D.G., Fletcher, A.E., Rudnicka, A.R., 2012. The estimated prevalence and incidence of late stage age related macular degeneration in the UK. Br. J. Ophthalmol. 96, 752-756.

Pennington, K.L., DeAngelis, M.M., 2016. Epidemiology of age-related macular degeneration (AMD): associations with cardiovascular disease phenotypes and lipid factors. Eye Vis. 3, 34-54.

Perkins, S.J., Nan, R., Li, K., Khan, S., Miller, A., 2012. Complement factor H-ligand interactions: self-association, multivalency and dissociation constants. Immunobiology 217, 281-297.

Puchtler, H., Meloen, S.N., 1978. Demonstration of phosphates in calcium deposits: a modification of von Kossa's reaction. Histochemistry 56, 177-185.

Rudnicka, A.R., Jarrar, Z., Wormald, R., Cook, D.G., Fletcher, A., Owen, C.G., 2012. Age and gender variations in age-related macular degeneration prevalence in populations of European ancestry: a meta-analysis. Ophthalmology 119, 571-580.

Sarks, S.H., 1976. Ageing and degeneration in the macular region: A clinico-pathological study. Br. J. Ophthalmol. 60, 324-341.

Timmann, C., Leippe, M., Horstmann, R. D., 1991. Two major serum components antigenically related to complement factor $\mathrm{H}$ are different glycosylation forms of a single protein with no factor H-like complement regulatory functions. J. Immunol. 146, $1265-1270$.

Thompson, R.B., Reffatto, V., Bundy, J.G., Kortvely, E., Flinn, J.M., Lanzirotti, A., Jones, E.A., McPhail, D.S., Fearn, S., Boldt, K., Ueffing, M., Ratu, S.G., Pauleikhoff, L., Bird, A.C., Lengyel, I., 2015. Identification of hydroxyapatite spherules provides new insight 
into subretinal pigment epithelial deposit formation in the aging eye. Proc. Natl. Acad. Sci. USA. 112, 1565-1570.

Toomey, C.B., Kelly, U., Saban, D.R., Bowes Rickman, C., 2015. Regulation of age-related macular degeneration-like pathology by complement factor H. Proc. Natl. Acad. Sci. USA. 112, 3040-3049.

van Asten, F., Simmons, M., Singhal, A., Keenan, T.D., Ratnapriya, R., Agron, E., Clemons, T.E., Swaroop, A., Lu, Z., Chew, E.Y., Age-Related Eye Disease Study 2 Research Group. A Deep Phenotype Association Study Reveals Specific Phenotype Associations with Genetic Variants in Age-related Macular Degeneration: Age-Related Eye Disease Study 2 (AREDS2) Report No. 14. Ophthamology, doi: 10.1016/j.ophtha.2017.09.023.

Yuan, X., Gu, X., Crabb, J.S., Yue, X., Shadrach, K, Hollyfield, J.G., Crabb, J.W., 2010. Quantitative proteomics: comparison of the macular Bruch membrane/choroid complex from age-related macular degeneration and normal eyes. Mol. Cell. Proteomics 9, 10311046. 


\section{Figure Legends}

Figure 1. Quantitative analysis of HAP-binding plasma proteins examined by SWATHMS. (A) Volcano plot of all quantified proteins displaying differences in relative abundance between CFH T/T1277 (TT) and C/C1277 (CC) groups. The plot represents the negative $\log _{10}$ of the p-value against the $\log _{2}$ of the fold change (FC). FC was calculated based on the relative abundance in TT/CC. Proteins shown by the open circles exhibited statistically significant differences between the homozygous groups $(\mathrm{p}<0.05)$ following binding and elution from HAP beads. The six proteins selected for further investigation are shown in bold. (B) The protein interaction network for 32 significantly changing HAP binding plasma proteins (between the homozygous CFH genotyped groups) as analysed by STRING software (https://string-db.org/). A network was drawn with seven differently coloured lines that represent different types of associations. A green line indicates neighbourhood evidence; red line indicates the presence of gene fusion evidence; a blue line indicates co-occurrence evidence; a purple line indicates experimental evidence; a yellow line indicates text-mining evidence; a light blue line indicates database evidence; and a black line indicates coexpression evidence. (C) HAP-binding plasma proteins displaying a significant difference in abundance between CFH T/T1277 (TT) and C/C1277 (CC) groups. Proteins with $\geq 1.5$ relative fold-change (both CC vs TT and TT vs CC) are shaded. FC was calculated based on the relative abundance in TT/CC. The six proteins selected for further investigation are shown in bold.

Figure 2. Detection of FHR1a and FHR1b-specific peptides in HAP-eluted fractions derived from CFH T/T1277 (TT), C/T1277 (CT) and C/C1277 (CC) plasma samples by SWATH-MS. (A) Amino acid sequence alignment of FHR1a and FHR1b proteins. Alignment was performed using ClustalW (“*” denote fully conserved residues; “:” denotes semi-conserved residues). Location of specific peptides in the sequences are shown by the grey-shaded box. (B) Plot of average intensities of the FHR1a-specific peptide in T/T1277 (TT), T/C1277 (CT) and C/C1277 (CC) groups. (C) Plot of average intensities of the FHR1bspecific peptide in T/T1277 (TT), T/C1277 (CT) and C/C1277 (CC) groups. Data in (B) and (C) are based on SWATH-MS data from HAP-eluted plasma-derived samples taken from the genotyped subjects. Statistical comparisons to the TT group were carried out by one-way ANOVA using Dunnet's multiple comparison test (ns, not significant; *, p<0.05; ***, $\mathrm{p}<0.001 ; * * * *, \mathrm{p}<0.0001)$. 
Figure 3. Quantitative analysis of six HAP-binding plasma proteins examined by enzyme-linked immunosorbent assay (ELISA) in HAP-eluted fractions and whole plasma. Relative concentrations of FHR1, FHR3, PZP, APOC4, C4A and C4B protein in HAP-eluted fractions (A) and whole plasma samples (B) from CFH T/T1277 (TT), C/T1277 (CT) and C/C1277 (CC) groups. Statistical comparisons to the TT group were carried out by one-way ANOVA using Dunnet's multiple comparison test (ns, not significant; *, p<0.05; **, $\mathrm{p}<0.01 ; * * *, \mathrm{p}<0.001 ; * * * *, \mathrm{p}<0.0001)$.

Figure 4. Immunolocalisation of HAP-binding proteins in the human RPE-choroid interface. Immunostaining was performed on sections from donated human eyes. RPE pigmentation shows natural auto-fluorescence. Most spherules (yellow arrows) in deposits (yellow star) are visualised by amyloid- $\beta$ immunolabelling using Alexa Fluor 568 (red). Localisation of complement factor H-related protein 1 (A), Complement factor H-related protein $3(B-C)$, pregnancy zone protein $(D-E)$, apolipoprotein $C 4(F)$, complement 4 A $(\mathrm{G}-\mathrm{H})$ and complement 4B (I) are visualised by immunolabelling using Alexa Fluor 488 (green and yellow in case of co-labelling with amyloid- $\beta$; white arrows). The presented observations were found in all samples analysed, therefore the images presented are representative. Scale bar is $10 \mu \mathrm{m}$. 


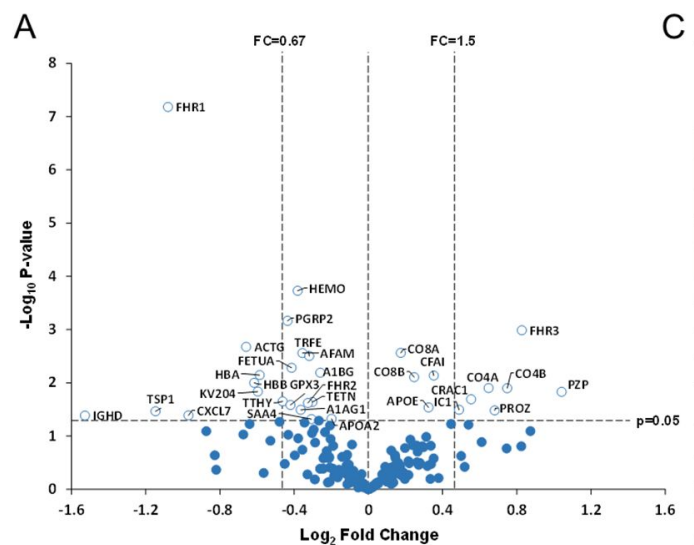

\begin{tabular}{|c|c|c|c|c|c|c|c|c|}
\hline Index & Uniprot ID & Uniprot Name & Group & $\begin{array}{l}\text { Logg Fold }_{2} \text { Change } \\
\text { T/CC }\end{array}$ & \begin{tabular}{|l|} 
Fold \\
Change \\
T/CC
\end{tabular} & P-value & Q-value & \multirow{12}{*}{$\begin{array}{c}\text { Increased in TT } \\
\text { relative to } \mathrm{CC}\end{array}$} \\
\hline 1 & P20742 & PZP & Pregnancy zone protein & 1.04 & 2.06 & $1.48 \mathrm{E}-02$ & $1.64 \mathrm{E}-01$ & \\
\hline 2 & Q02985 & FHR3 & $\begin{array}{l}\text { Complement factor } \mathrm{H} \text {-related } \\
\text { protein } 3\end{array}$ & 0.83 & 1.77 & $1.03 E-03$ & $5.43 \mathrm{E}-02$ & \\
\hline 3 & POCOL5 & CO4B & Complement C4-B & 0.75 & 1.68 & $1.26 \mathrm{E}-02$ & $1.56 \mathrm{E}-01$ & \\
\hline 4 & P22891 & PROZ & Vitamin K-dependent protein Z & 0.68 & 1.60 & $3.29 \mathrm{E}-02$ & 239E-01 & \\
\hline 5 & POCOL4 & $\operatorname{COAA}$ & Complement C4-A & 0.65 & 1.57 & $1.25 \mathrm{E}-02$ & $1.56 \mathrm{E}-01$ & \\
\hline 6 & Q9NQ79 & CRAC1 & Cartilage acidic protein 1 & 0.55 & 1.47 & $2.03 E-02$ & $2.04 \mathrm{E}-01$ & \\
\hline 7 & P05155 & IC1 & Plasma protease $\mathrm{C} 1$ inhibitor & 0.49 & 1.40 & $3.21 \mathrm{E}-02$ & $2.39 \mathrm{E}-01$ & \\
\hline 8 & P05156 & CFAI & Complement factor I & 0.35 & 1.28 & $7.30 \mathrm{E}-03$ & $1.27 \mathrm{E}-01$ & \\
\hline 9 & P02649 & APOE & Apolipoprotein E & 0.32 & 1.25 & $2.89 \mathrm{E}-02$ & $2.35 \mathrm{E}-01$ & \\
\hline 10 & P07358 & $\mathrm{COBB}$ & $\begin{array}{l}\text { Complement component } \mathrm{C} 8 \text { beta } \\
\text { chain }\end{array}$ & 0.25 & 1.19 & $7.80 \mathrm{E}-03$ & $1.27 \mathrm{E}-01$ & \\
\hline 11 & P07357 & $\operatorname{COBA}$ & $\begin{array}{l}\text { Complement component C8 alpha } \\
\text { chain }\end{array}$ & 0.17 & 1.13 & $2.74 \mathrm{E}-03$ & $8.25 \mathrm{E}-02$ & \\
\hline 12 & P02652 & APOA2 & \begin{tabular}{|l|} 
Apolipoprotein A-ll \\
\end{tabular} & -0.20 & 0.87 & $4.73 \mathrm{E}-02$ & $2.97 \mathrm{E}-01$ & \multirow{21}{*}{$\begin{array}{c}\text { Decreased in TT } \\
\text { relative to CC }\end{array}$} \\
\hline 13 & P04217 & A1BG & Alpha-1B-glycoprotein & -0.26 & 0.84 & $6.46 \mathrm{E}-03$ & $1.27 \mathrm{E}-01$ & \\
\hline 14 & P05452 & TETN & Tetranectin & -0.30 & 0.81 & $2.29 \mathrm{E}-02$ & $2.10 \mathrm{E}-01$ & \\
\hline 15 & P35542 & SAA4 & Serum amyloid A.4 protein & -0.31 & 0.81 & $4.79 \mathrm{E}-02$ & 2.97E-01 & \\
\hline 16 & P02787 & TRFE & Serotransferrin & -0.32 & 0.80 & $3.13 \mathrm{E}-03$ & $8.25 \mathrm{E}-02$ & \\
\hline 17 & $\mathrm{P} 36980$ & FHR2 & Complement factor $\mathrm{H}$-related protein & -0.33 & 0.80 & $2.39 \mathrm{E}-02$ & $2.10 \mathrm{E}-01$ & \\
\hline 18 & P43652 & AFAM & Afamin & -0.36 & 0.78 & $2.76 \mathrm{E}-03$ & $8.25 \mathrm{E}-02$ & \\
\hline 19 & P02763 & A1AG1 & Alpha-1-acid glycoprotein 1 & -0.36 & 0.78 & $3.21 \mathrm{E}-02$ & $2.39 \mathrm{E}-01$ & \\
\hline 20 & P02790 & HEMO & Hemopexin & -0.38 & 0.77 & $1.86 \mathrm{E}-04$ & $1.97 \mathrm{E}-02$ & \\
\hline 21 & P02765 & FETUA & Alpha-2-HS-glycoprotein & -0.41 & 0.75 & $5.22 \mathrm{E}-03$ & $1.22 \mathrm{E}-01$ & \\
\hline 22 & P22352 & GPX3 & Glutathione peroxidase 3 & -0.42 & 0.75 & $2.60 \mathrm{E}-02$ & $2.20 \mathrm{E}-01$ & \\
\hline 23 & Q96PD5 & PGRP2 & $\begin{array}{l}\text { N-acetylmuramoyl-L-alanine } \\
\text { amidase }\end{array}$ & -0.44 & 0.74 & $6.86 \mathrm{E}-04$ & $4.82 \mathrm{E}-02$ & \\
\hline 24 & P02766 & $\pi H Y$ & Transthyretin & -0.46 & 0.73 & $2.23 \mathrm{E}-02$ & $2.10 \mathrm{E}-01$ & \\
\hline 25 & P69905 & HBA & Hemoglobin subunit alpha & -0.59 & 0.67 & $7.15 \mathrm{E}-03$ & $1.27 \mathrm{E}-01$ & \\
\hline 26 & P01617 & KV204 & Ig kappa chain V-II region TEW & -0.60 & 0.66 & 1.46E-02 & $1.64 \mathrm{E}-01$ & \\
\hline 27 & P68871 & HBB & Hemoglobin subunit beta & -0.61 & 0.65 & $1.00 \mathrm{E}-02$ & $1.51 \mathrm{E}-01$ & \\
\hline 28 & P63261 & ACTG & Actin, cytoplasmic 2 & -0.66 & 0.63 & $2.11 \mathrm{E}-03$ & $8.25 \mathrm{E}-02$ & \\
\hline 29 & P02775 & CXCL7 & Platelet basic protein & -0.97 & 0.51 & $4.09 \mathrm{E}-02$ & 271E-01 & \\
\hline 30 & Q03591 & FHR1 & $\begin{array}{l}\text { Complement factor H-related } \\
\text { protein } 1\end{array}$ & -1.08 & 0.47 & $6.58 \mathrm{E}-08$ & $1.39 \mathrm{E}-05$ & \\
\hline 31 & P07996 & TSP1 & Thrombospondin-1 & -1.15 & 0.45 & $3.42 \mathrm{E}-02$ & $241 \mathrm{E}-01$ & \\
\hline 32 & P01880 & IGHD & Ig delta chain $\mathrm{C}$ region & -1.53 & 0.35 & $4.12 \mathrm{E}-02$ & $2.71 \mathrm{E}-01$ & \\
\hline
\end{tabular}

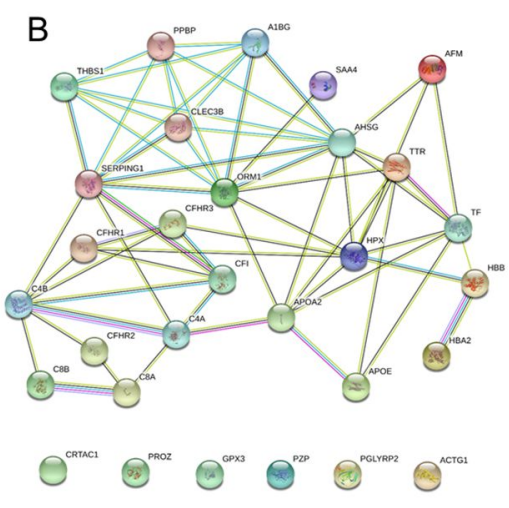


FHR1 a FHR1b

FHR1 a FHR1b

FHR1a FHR1b

FHR1a FHR1b
MWLLVSVI LISRIS SVGGEA TFCDFPKINHGI LYDEEKYKP FSQVPT GEVFYY SCEYNFVSP SKS FWTRIT CTEEGWSPT PKC LRLCFF P MWLLVSVI LISRIS SVGGEATFCDFPKINHGI LYDEEKYKP FSQVPT GEVFYY SCEYNFVSP SKS FWTRITCTE EGWSPT PKC LRLCFF P

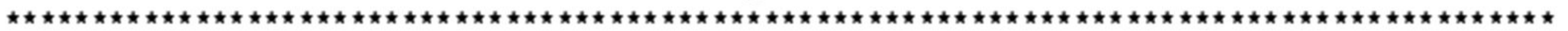

FVENGHSE SSGQTHLEGDTVQII CNT GYRLQNNENNISCVERGWSTP PKCRSTDTSCVNPPTVQNAHI LSRQMSKYP SGERVRYECRSPY FVENGHSE SSGQTHLEGDTVQII CNTGYRLQNNENNISCVERGWSTP PKCRSTDTSCVNPPTVQNAYIVSRQMSKYP SGERVRYQCRSPY

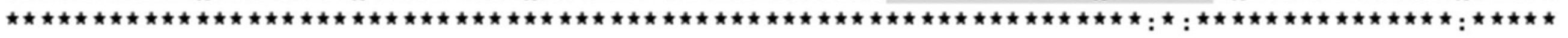

EMFGD EEVMCLNGNWTE PPQCKD STGKCGPPP PIDNGD ITS FPL SVYAPASSVEYQCQN LYQ LEGNKRITCRNGQWSEPPKCLHPCVISR EMFGD EEVMCLNGNWTE PPQCKD STGKCGPPP PIDNGD ITS FPLSVYAPASSVEYQCQN LYQ LEGNKRITCRNGQWS EPPKCLHPCVISR

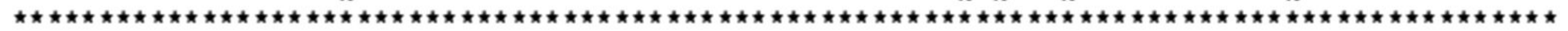

EIMENYNIALRWTAKQKLYLRTGESAEFVCKRGYRLSSRSHTLRTTCWDGKLEYPTCAKR EIMENYNIALRWTAKQKLYLRTGESAEFVCKRGYRLSSRSHTLRTTCWDGKLEYPTCAKR

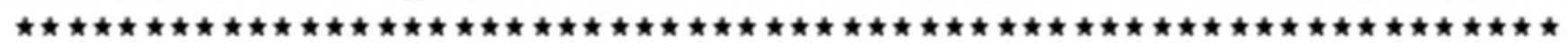

B

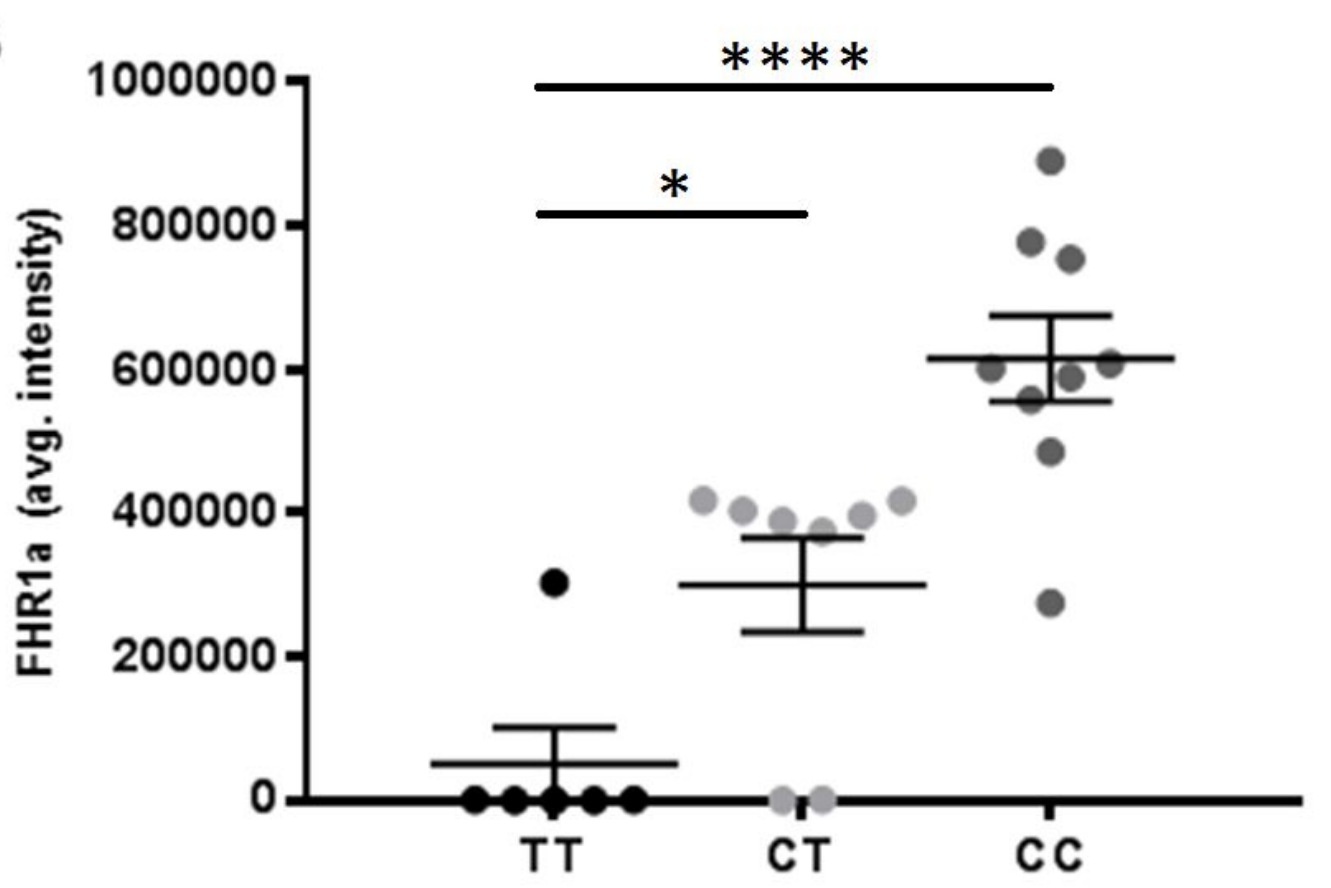

C

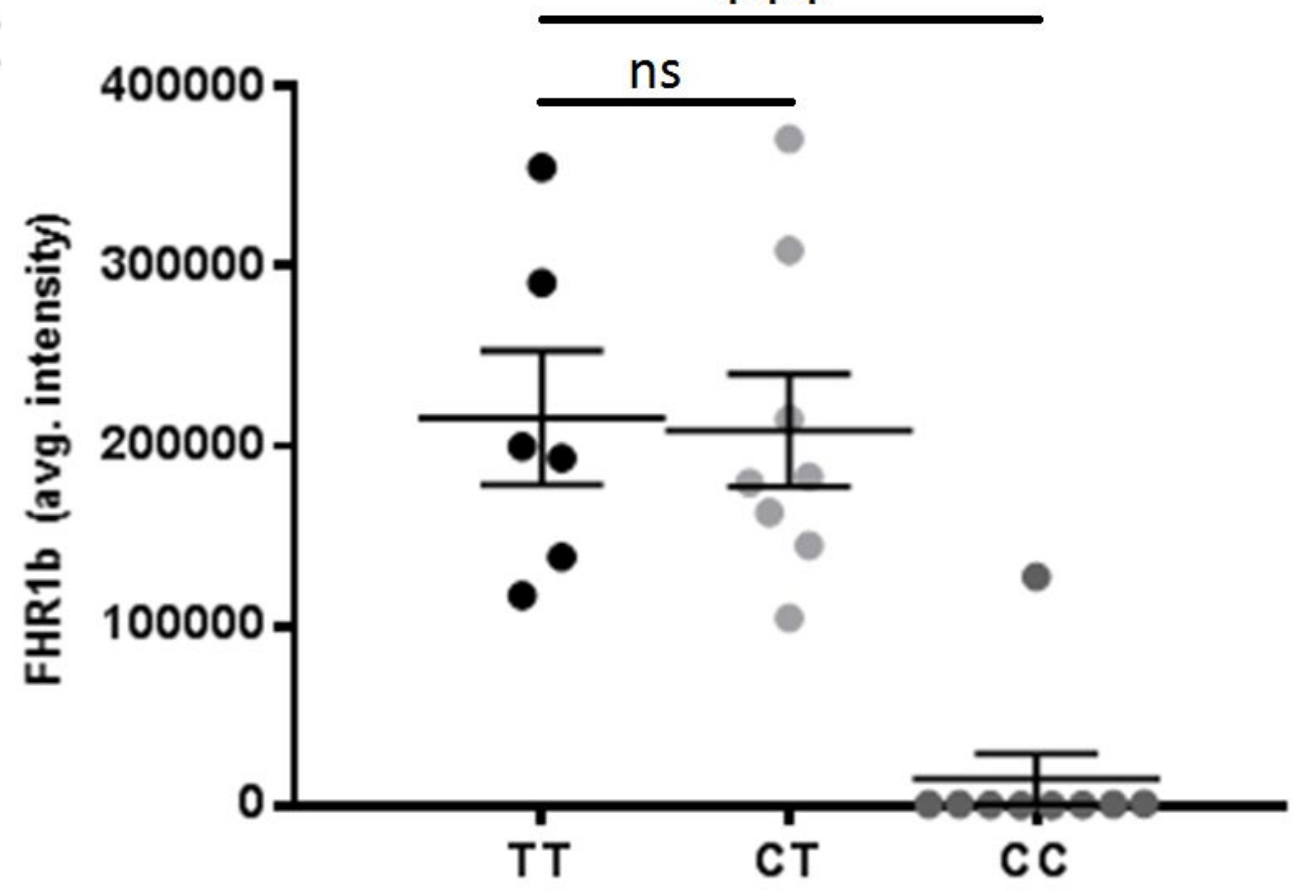



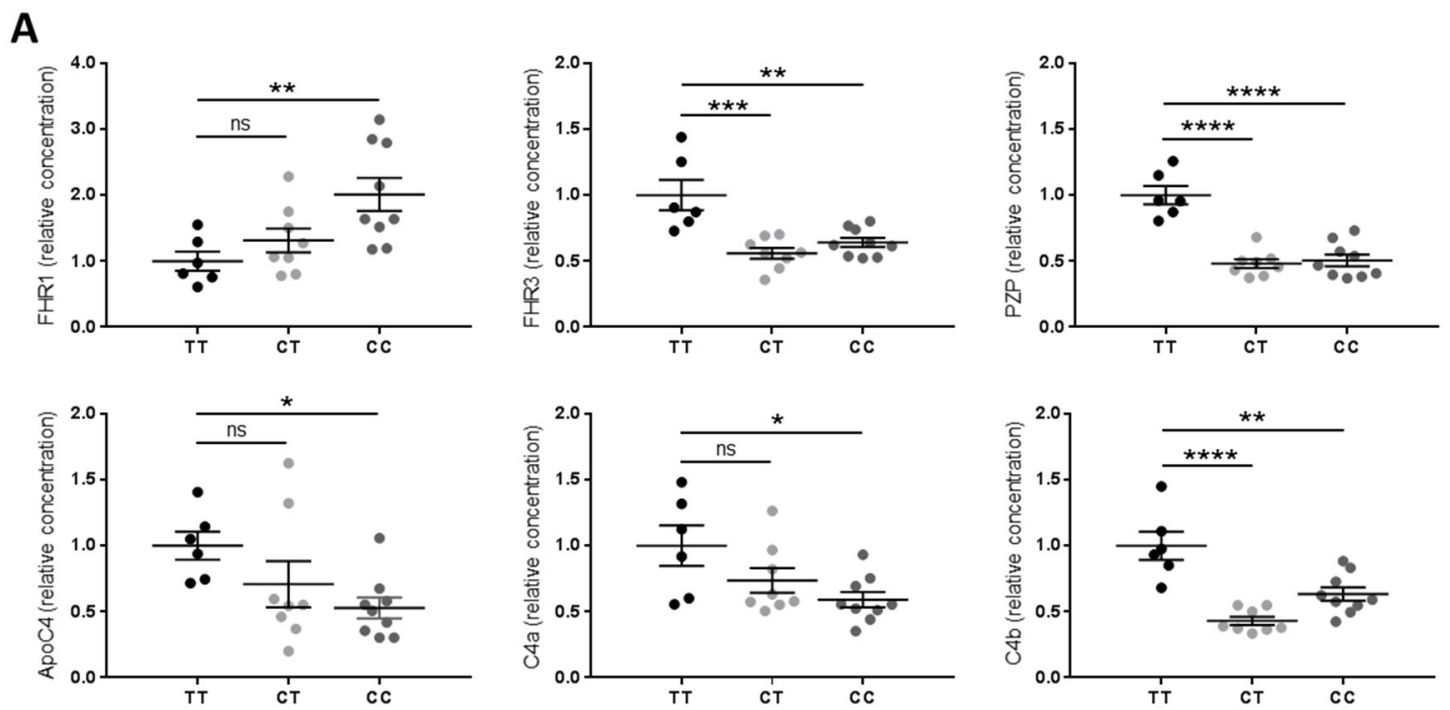

B
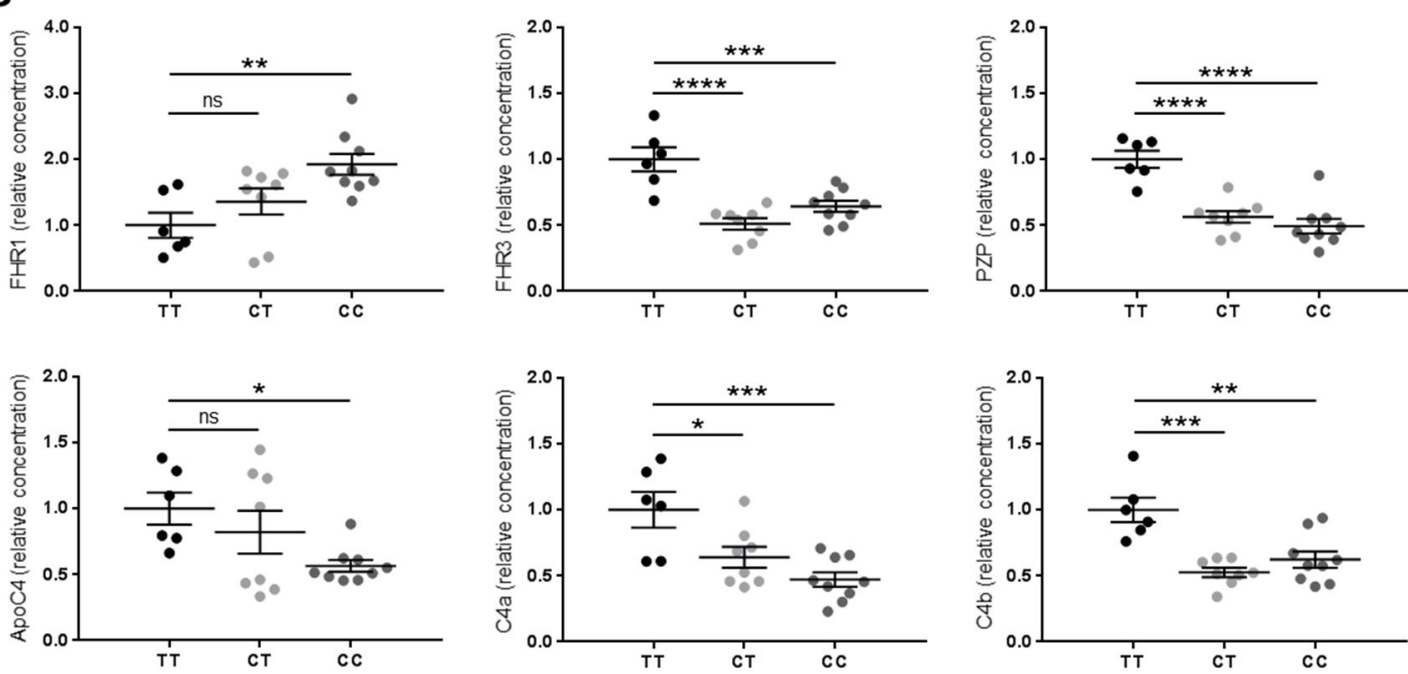


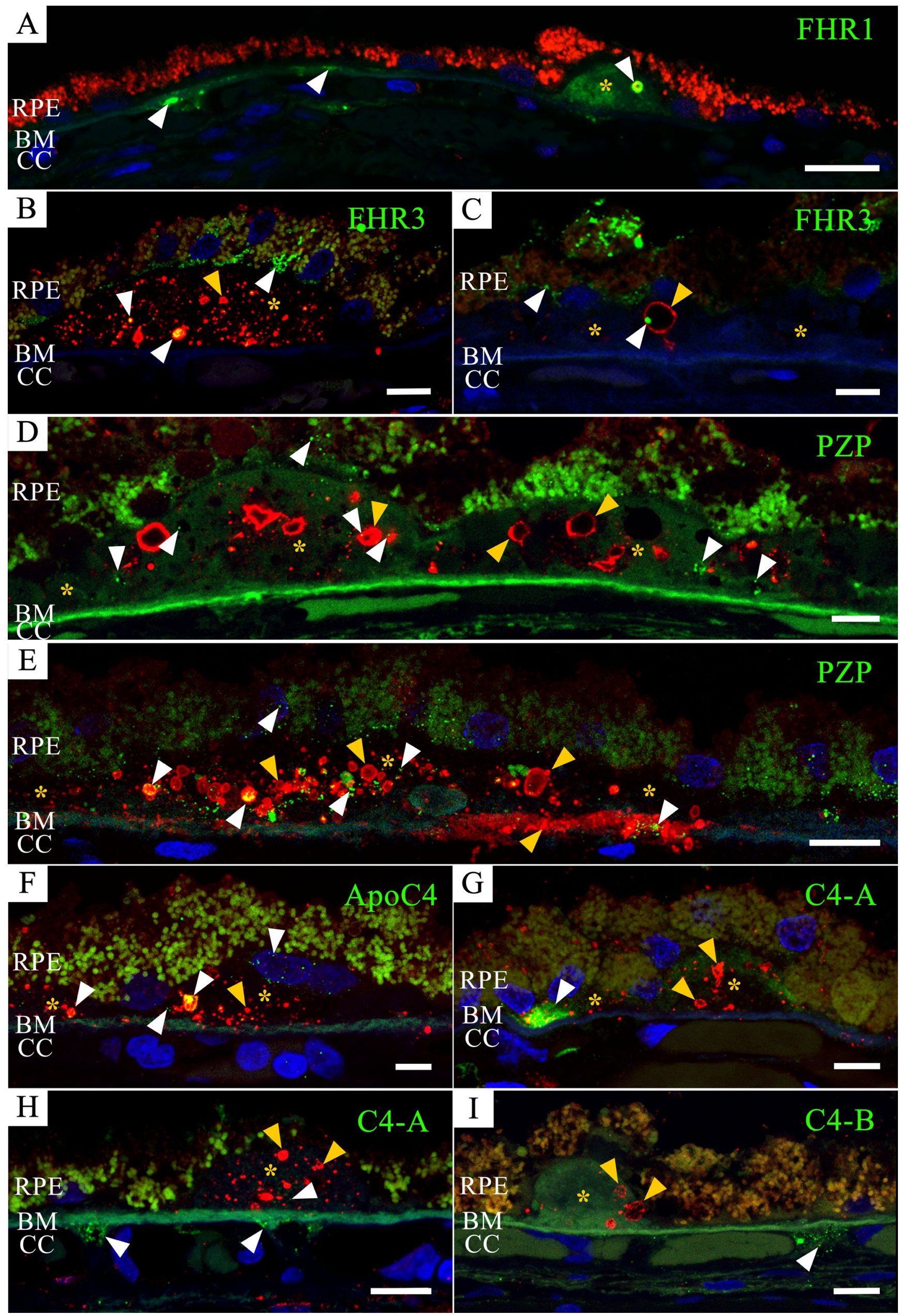




\section{Supplementary Data}

Table S1: Participant information showing age, sex and CFH genotype (either T/T1277 (TT), $\mathrm{T} / \mathrm{C} 1277$ (CT) or C/C1277 (CC)) of the 23 individuals in this study.

\begin{tabular}{|l|l|l|l|}
\hline $\begin{array}{l}\text { Participant } \\
\text { Number }\end{array}$ & Genotype & Sex & Age \\
\hline 1 & CT & F & 77 \\
\hline 2 & CT & M & 81 \\
\hline 3 & CC & M & 79 \\
\hline 4 & CT & M & 75 \\
\hline 5 & CT & F & 86 \\
\hline 6 & CC & M & 65 \\
\hline 7 & CT & M & 85 \\
\hline 8 & TT & F & 90 \\
\hline 9 & CT & M & 80 \\
\hline 10 & CC & F & 64 \\
\hline 11 & TT & F & 77 \\
\hline 12 & TT & F & 84 \\
\hline 13 & CC & M & 80 \\
\hline 14 & CC & F & 84 \\
\hline 15 & CC & M & 68 \\
\hline 16 & TT & F & 86 \\
\hline 17 & CT & M & 84 \\
\hline 18 & TT & F & 81 \\
\hline 19 & CC & M & 80 \\
\hline 20 & CC & F & 87 \\
\hline 21 & TT & F & 82 \\
\hline 22 & CC & F & 69 \\
\hline 23 & CT & M & 78 \\
\hline
\end{tabular}


Table S2: List of HAP-binding plasma proteins detected and quantified (based on two or more peptides) in all 23 participant samples. For each protein the Uniprot ID and name, number of peptides, and average peak intensities for C/T1277 (CT), C/C1277 (CC) or T/T1277 (TT) groups are provided. The peptide number indicates the total number of peptides used for protein quantitation that were consistently detected across all samples. The quantitative value for each unique peptide originates from summing the integrated area of the selected $b$ and $y$-ions for this peptide and is an average value for each genotypic group (indicated as average intensity). ' $\sigma$ ' represents the standard deviation

\begin{tabular}{|c|c|c|c|c|c|c|c|c|c|}
\hline $\begin{array}{l}\text { Ind } \\
\text { ex }\end{array}$ & $\begin{array}{l}\text { Uniprot } \\
\text { number }\end{array}$ & $\begin{array}{l}\text { Unipro } \\
\text { t name }\end{array}$ & $\begin{array}{l}\text { Pepti } \\
\text { des }\end{array}$ & $\begin{array}{l}\text { Average } \\
\text { peak } \\
\text { intensity } \\
\text { CT }\end{array}$ & $\begin{array}{l}\text { Average } \\
\text { peak } \\
\text { intensity } \\
\text { CC }\end{array}$ & $\begin{array}{l}\text { Average } \\
\text { peak } \\
\text { intensity } \\
\text { TT }\end{array}$ & $\sigma \mathrm{CT}$ & $\sigma C C$ & $\sigma \mathrm{TT}$ \\
\hline 1 & P04114 & APOB & 10 & $1.20 \mathrm{E}+07$ & $9.99 \mathrm{E}+06$ & $1.09 \mathrm{E}+07$ & $2.86 \mathrm{E}+06$ & $2.27 \mathrm{E}+06$ & $3.50 \mathrm{E}+06$ \\
\hline 2 & P01024 & $\mathrm{CO} 3$ & 10 & $2.92 \mathrm{E}+07$ & $2.92 \mathrm{E}+07$ & $2.84 \mathrm{E}+07$ & $9.29 E+06$ & $7.98 \mathrm{E}+06$ & $8.59 E+06$ \\
\hline 3 & P08603 & $\mathrm{CFAH}$ & 10 & $1.26 \mathrm{E}+07$ & $1.15 \mathrm{E}+07$ & $1.09 \mathrm{E}+07$ & $8.65 E+05$ & $1.59 \mathrm{E}+06$ & $2.81 E+06$ \\
\hline 4 & P01023 & A2MG & 10 & $1.21 \mathrm{E}+07$ & $1.50 \mathrm{E}+07$ & $1.41 \mathrm{E}+07$ & $2.58 \mathrm{E}+06$ & $3.63 \mathrm{E}+06$ & $2.15 \mathrm{E}+06$ \\
\hline 5 & P02768 & ALBU & 10 & $1.43 \mathrm{E}+07$ & $1.51 \mathrm{E}+07$ & $1.31 \mathrm{E}+07$ & $1.12 \mathrm{E}+07$ & $1.42 \mathrm{E}+07$ & $1.79 \mathrm{E}+07$ \\
\hline 6 & P00450 & CERU & 10 & $1.52 \mathrm{E}+07$ & $1.41 E+07$ & $1.50 \mathrm{E}+07$ & $2.81 E+06$ & $3.07 E+06$ & $1.91 \mathrm{E}+06$ \\
\hline 7 & P02787 & TRFE & 10 & $1.41 \mathrm{E}+07$ & $1.70 \mathrm{E}+07$ & $1.36 \mathrm{E}+07$ & $1.23 \mathrm{E}+06$ & $2.94 \mathrm{E}+06$ & $2.64 \mathrm{E}+06$ \\
\hline 8 & P01031 & $\mathrm{CO} 5$ & 10 & $3.01 \mathrm{E}+06$ & $2.81 \mathrm{E}+06$ & $3.06 \mathrm{E}+06$ & $8.67 E+05$ & $1.07 \mathrm{E}+06$ & $1.20 \mathrm{E}+06$ \\
\hline 9 & P02671 & FIBA & 10 & $1.33 \mathrm{E}+07$ & $1.31 \mathrm{E}+07$ & $1.57 \mathrm{E}+07$ & $3.11 E+06$ & $3.38 \mathrm{E}+06$ & $6.05 E+06$ \\
\hline 10 & P00751 & CFAB & 10 & $1.09 \mathrm{E}+07$ & $9.62 \mathrm{E}+06$ & $9.92 \mathrm{E}+06$ & $1.66 \mathrm{E}+06$ & $2.76 \mathrm{E}+06$ & $2.67 E+06$ \\
\hline 11 & $\mathrm{P} 02$ & FIBB & 10 & $1 \mathrm{E}+07$ & $9 \mathrm{E}+07$ & $\mathrm{E}+07$ & $6 \mathrm{E}+06$ & +06 & \\
\hline 12 & P02751 & FINC & 10 & $2.91 \mathrm{E}+06$ & $3.08 E+06$ & $2.26 \mathrm{E}+06$ & $2.08 \mathrm{E}+06$ & $2.36 \mathrm{E}+06$ & $2.28 \mathrm{E}+06$ \\
\hline 13 & P00747 & PLMN & 10 & $1.96 \mathrm{E}+06$ & $1.94 \mathrm{E}+06$ & $2.07 E+06$ & $5.63 E+05$ & $3.95 \mathrm{E}+05$ & $5.86 \mathrm{E}+05$ \\
\hline 14 & P02679 & FIBG & 10 & $9.67 \mathrm{E}+06$ & $9.71 \mathrm{E}+06$ & $1.21 \mathrm{E}+07$ & $2.15 \mathrm{E}+06$ & $3.12 \mathrm{E}+06$ & $4.81 \mathrm{E}+06$ \\
\hline 15 & P04003 & C4BPA & 10 & $1.23 \mathrm{E}+07$ & $1.19 \mathrm{E}+07$ & $1.16 \mathrm{E}+07$ & $1.88 \mathrm{E}+06$ & $2.81 \mathrm{E}+06$ & $1.65 \mathrm{E}+06$ \\
\hline 16 & P19823 & ITIH2 & 10 & $9.29 \mathrm{E}+06$ & $9.42 \mathrm{E}+06$ & $1.05 \mathrm{E}+07$ & $1.28 \mathrm{E}+06$ & $2.78 \mathrm{E}+06$ & $3.58 \mathrm{E}+06$ \\
\hline 17 & P00734 & THRB & 10 & $2 \mathrm{E}+07$ & $1.03 \mathrm{E}+07$ & $1.19 \mathrm{E}+07$ & $41 \mathrm{E}+06$ & $32 \mathrm{E}+06$ & $35 E+06$ \\
\hline 18 & P02748 & CO9 & 10 & $E+06$ & $7.62 E+06$ & $\mathrm{E}+06$ & $2 \mathrm{E}+06$ & $2.15 \mathrm{E}+06$ & $8 \mathrm{E}+06$ \\
\hline 19 & P06396 & GELS & 10 & $1 \mathrm{E}+06$ & $2.32 \mathrm{E}+06$ & $3 \mathrm{E}+06$ & $4.44 \mathrm{E}+05$ & $4.60 \mathrm{E}+05$ & $8 \mathrm{E}+05$ \\
\hline 20 & P02647 & APOA1 & 10 & $1.06 \mathrm{E}+07$ & $1.39 \mathrm{E}+07$ & $1.31 \mathrm{E}+07$ & $1.63 E+06$ & $1.48 \mathrm{E}+06$ & $43 \mathrm{E}+06$ \\
\hline 21 & P10643 & $\mathrm{CO}$ & 10 & $E+06$ & $7 \mathrm{E}+06$ & $8 \mathrm{E}+06$ & $94 \mathrm{E}+05$ & $\mathrm{E}+05$ & $E+05$ \\
\hline 22 & P00738 & HPT & 10 & $1.24 \mathrm{E}+07$ & $1.09 \mathrm{E}+07$ & $1.13 \mathrm{E}+07$ & $2.35 E+06$ & $4.73 E+06$ & $2.80 \mathrm{E}+06$ \\
\hline 23 & P01871 & IGHM & 10 & $7.89 \mathrm{E}+06$ & $6.45 E+06$ & $7.04 \mathrm{E}+06$ & $2.89 E+06$ & $2.65 \mathrm{E}+06$ & $4.02 E+06$ \\
\hline 24 & P19827 & $\mathrm{ITIH} 1$ & 10 & $7.04 \mathrm{E}+06$ & $7.44 \mathrm{E}+06$ & $7.99 \mathrm{E}+06$ & $1.05 \mathrm{E}+06$ & $2.25 \mathrm{E}+06$ & $2.85 \mathrm{E}+06$ \\
\hline 25 & P01009 & A1AT & 10 & $7.58 \mathrm{E}+06$ & $8.97 E+06$ & $8.13 E+06$ & $9.28 \mathrm{E}+05$ & $2.11 \mathrm{E}+06$ & $1.54 \mathrm{E}+06$ \\
\hline 26 & Q14624 & ITIH4 & 10 & $1.48 \mathrm{E}+06$ & $2.05 E+06$ & $1.80 \mathrm{E}+06$ & $2.36 \mathrm{E}+05$ & $4.35 E+05$ & $5.28 \mathrm{E}+05$ \\
\hline 27 & P06727 & APOA4 & 10 & $1.14 \mathrm{E}+06$ & $1.23 \mathrm{E}+06$ & $1.41 \mathrm{E}+06$ & $4.74 \mathrm{E}+05$ & $3.89 \mathrm{E}+05$ & $2.42 \mathrm{E}+05$ \\
\hline 28 & P07225 & PROS & 10 & $4.14 \mathrm{E}+06$ & $3.74 E+06$ & $3.73 E+06$ & $1.06 \mathrm{E}+06$ & $9.29 \mathrm{E}+05$ & $6.66 \mathrm{E}+05$ \\
\hline 29 & P13671 & $\mathrm{CO} 6$ & 10 & $1.69 \mathrm{E}+06$ & $1.37 \mathrm{E}+06$ & $1.60 \mathrm{E}+06$ & $4.34 \mathrm{E}+05$ & $2.86 \mathrm{E}+05$ & $5.30 \mathrm{E}+05$ \\
\hline 30 & P02774 & VTDB & 10 & $2.94 \mathrm{E}+06$ & $3.65 E+06$ & $3.11 \mathrm{E}+06$ & $4.64 \mathrm{E}+05$ & $8.26 \mathrm{E}+05$ & $7.87 \mathrm{E}+05$ \\
\hline 31 & P01042 & KNG1 & 10 & $4.92 \mathrm{E}+06$ & $5.51 \mathrm{E}+06$ & $5.63 \mathrm{E}+06$ & $1.93 \mathrm{E}+06$ & $1.63 \mathrm{E}+06$ & $1.62 \mathrm{E}+06$ \\
\hline 32 & P02790 & HEMO & 10 & $1.04 \mathrm{E}+07$ & $1.36 \mathrm{E}+07$ & $1.05 \mathrm{E}+07$ & $1.30 \mathrm{E}+06$ & $1.92 \mathrm{E}+06$ & $2.02 \mathrm{E}+06$ \\
\hline 33 & P07358 & $\mathrm{CO} 8 \mathrm{~B}$ & 10 & $2.57 \mathrm{E}+06$ & $2.09 E+06$ & $2.48 \mathrm{E}+06$ & $3.64 \mathrm{E}+05$ & $2.98 \mathrm{E}+05$ & $4.01 E+05$ \\
\hline 34 & P04196 & HRG & 10 & $6.26 \mathrm{E}+06$ & $5.78 \mathrm{E}+06$ & $6.94 \mathrm{E}+06$ & $1.59 \mathrm{E}+06$ & $2.81 \mathrm{E}+06$ & $1.53 E+06$ \\
\hline 35 & P02749 & $\mathrm{APOH}$ & 10 & $2.20 \mathrm{E}+07$ & $1.77 \mathrm{E}+07$ & $1.86 \mathrm{E}+07$ & $3.59 E+06$ & $4.00 \mathrm{E}+06$ & $3.72 E+06$ \\
\hline 36 & P03952 & KLKB1 & 10 & $2.12 \mathrm{E}+06$ & $1.97 \mathrm{E}+06$ & $2.17 \mathrm{E}+06$ & $5.85 E+05$ & $5.50 \mathrm{E}+05$ & $3.84 \mathrm{E}+05$ \\
\hline 37 & P02649 & APOE & 10 & $6.95 \mathrm{E}+06$ & $5.04 \mathrm{E}+06$ & $6.31 E+06$ & $2.80 \mathrm{E}+06$ & $8.61 \mathrm{E}+05$ & $2.18 \mathrm{E}+06$ \\
\hline
\end{tabular}




\begin{tabular}{|c|c|c|c|c|c|c|c|c|c|}
\hline 38 & 09871 & C1S & 10 & $1.39 \mathrm{E}+06$ & $1.38 \mathrm{E}+06$ & $1.52 \mathrm{E}+06$ & $3.31 E+05$ & $3.03 E+05$ & $3.51 \mathrm{E}+05$ \\
\hline 39 & P01011 & AACT & 10 & $5.89 E+06$ & $7.41 \mathrm{E}+06$ & $6.83 \mathrm{E}+06$ & $8.50 E+05$ & $1.47 E+06$ & $2.08 \mathrm{E}+06$ \\
\hline 40 & 36955 & EDF & 10 & $4.31 \mathrm{E}+06$ & $3.20 E+06$ & $3.19 E+06$ & $5.95 \mathrm{E}+05$ & $6.93 \mathrm{E}+05$ & $4.87 E+05$ \\
\hline 41 & 01008 & NT3 & 10 & $3.41 \mathrm{E}+06$ & $4.15 \mathrm{E}+06$ & $3.83 \mathrm{E}+06$ & $3.64 \mathrm{E}+05$ & $6.79 \mathrm{E}+05$ & $6.11 \mathrm{E}+05$ \\
\hline 42 & 04217 & $1 \mathrm{BG}$ & 10 & $3.29 E+06$ & $4.31 E+06$ & $3.60 \mathrm{E}+06$ & $3.47 \mathrm{E}+05$ & $6.01 \mathrm{E}+05$ & $7.21 \mathrm{E}+05$ \\
\hline 43 & 12259 & A5 & 10 & $5.15 \mathrm{E}+05$ & $4.76 \mathrm{E}+05$ & $4.56 \mathrm{E}+05$ & $1.43 E+05$ & $2.28 \mathrm{E}+05$ & $1.22 \mathrm{E}+05$ \\
\hline 44 & 00748 & A12 & 10 & $4.90 \mathrm{E}+06$ & $4.67 \mathrm{E}+06$ & $5.51 \mathrm{E}+06$ & $7.39 E+05$ & $1.54 \mathrm{E}+06$ & $1.64 \mathrm{E}+06$ \\
\hline 45 & & $1 \mathrm{R}$ & 10 & $1.59 \mathrm{E}+06$ & $1.54 \mathrm{E}+06$ & $1.66 \mathrm{E}+06$ & $4.10 \mathrm{E}+05$ & $4.22 \mathrm{E}+05$ & $3.22 \mathrm{E}+05$ \\
\hline 46 & 05155 & IC1 & 10 & $5.30 \mathrm{E}+06$ & $6.16 \mathrm{E}+06$ & $8.65 \mathrm{E}+06$ & $1.42 \mathrm{E}+06$ & $2.90 \mathrm{E}+06$ & $3.30 \mathrm{E}+06$ \\
\hline 47 & 8519 & $\mathrm{POA}$ & 10 & $6.71 E+05$ & $7.63 \mathrm{E}+05$ & $7.35 E+05$ & $1.00 \mathrm{E}+06$ & $9.08 \mathrm{E}+05$ & $6.65 \mathrm{E}+05$ \\
\hline 48 & P07357 & $\mathrm{O} A \mathrm{~A}$ & 10 & $2.74 \mathrm{E}+06$ & $2.41 \mathrm{E}+06$ & $2.72 E+06$ & $3.74 \mathrm{E}+05$ & $1.43 E+05$ & $3.71 \mathrm{E}+05$ \\
\hline 49 & 10909 & CLUS & 10 & $2.99 E+06$ & $3.54 \mathrm{E}+06$ & $3.26 \mathrm{E}+06$ & $2.39 E+05$ & $7.06 \mathrm{E}+05$ & $5.71 \mathrm{E}+05$ \\
\hline 50 & 06681 & $\mathrm{CO} 2$ & 10 & $6.21 E+05$ & $6.34 \mathrm{E}+05$ & $7.08 \mathrm{E}+05$ & $1.24 \mathrm{E}+05$ & $2.02 \mathrm{E}+05$ & $1.94 \mathrm{E}+05$ \\
\hline 51 & & & 10 & $E+06$ & $E+06$ & & $7.42 \mathrm{E}+05$ & $E+06$ & $.21 \mathrm{E}+06$ \\
\hline 52 & & FAI & 10 & $1.24 \mathrm{E}+06$ & $1.13 \mathrm{E}+06$ & $1.45 \mathrm{E}+06$ & $2.51 E+05$ & $2.25 \mathrm{E}+05$ & $3.88 \mathrm{E}+05$ \\
\hline 53 & P35858 & LS & 10 & $1.10 \mathrm{E}+06$ & $1.01 \mathrm{E}+06$ & $1.08 \mathrm{E}+06$ & $3.96 \mathrm{E}+05$ & $2.21 \mathrm{E}+05$ & $2.36 \mathrm{E}+05$ \\
\hline 54 & 52 & & 10 & $5.20 \mathrm{E}+05$ & $E+05$ & $5 \mathrm{E}+05$ & $1.18 \mathrm{E}+05$ & $1.27 \mathrm{E}+05$ & $5.91 \mathrm{E}+04$ \\
\hline 55 & & D5L & 10 & $3.41 \mathrm{E}+06$ & $\mathrm{E}+06$ & $E+06$ & $1.63 \mathrm{E}+06$ & $1.22 \mathrm{E}+06$ & $2.07 E+06$ \\
\hline 56 & Q92954 & PRG4 & 10 & $5.12 \mathrm{E}+05$ & $5.08 \mathrm{E}+05$ & $4.75 \mathrm{E}+05$ & $2.09 \mathrm{E}+05$ & $1.29 \mathrm{E}+05$ & $6.41 E+04$ \\
\hline 57 & & TUA & 10 & $2.60 \mathrm{E}+06$ & $=06$ & +06 & $7.16 \mathrm{E}+05$ & $E+05$ & $3.68 \mathrm{E}+05$ \\
\hline 58 & & $2 A P$ & 10 & $E+05$ & $=05$ & $E+05$ & $.06 \mathrm{E}+04$ & $5 \mathrm{E}+05$ & $.49 \mathrm{E}+04$ \\
\hline 59 & & GRP2 & 10 & $3.77 E+05$ & $4.78 \mathrm{E}+05$ & $\mathrm{E}+05$ & $5.56 E+04$ & $7.14 \mathrm{E}+04$ & $6.31 E+04$ \\
\hline 60 & 22 & & 10 & $E+05$ & $E+05$ & +05 & $1.39 \mathrm{E}+05$ & $E+05$ & $2.00 \mathrm{E}+05$ \\
\hline 61 & & & 10 & +05 & +05 & & $70 \mathrm{E}+05$ & $=05$ & $\mathrm{E}+05$ \\
\hline 62 & & & 10 & +05 & $1.14 \mathrm{E}+06$ & & $32 \mathrm{E}+05$ & $2.47 \mathrm{E}+05$ & $2.14 \mathrm{E}+05$ \\
\hline 63 & & ON1 & 10 & $6.67 \mathrm{E}+05$ & $5.92 E+05$ & $\mathrm{E}+05$ & $1.45 \mathrm{E}+05$ & $2.53 E+05$ & $2.96 \mathrm{E}+05$ \\
\hline 64 & & & 10 & $E+06$ & $E+06$ & $E+06$ & $05 \mathrm{E}+05$ & $E+05$ & $.51 \mathrm{E}+05$ \\
\hline 65 & & $\mathrm{A2G}$ & 10 & $3.36 \mathrm{E}+05$ & $3.96 \mathrm{E}+05$ & $E+05$ & $9.61 \mathrm{E}+04$ & $1.59 \mathrm{E}+05$ & $6.55 E+04$ \\
\hline 66 & & & 10 & $E+06$ & +05 & & $5.05 E+05$ & $3.86 \mathrm{E}+05$ & $5.28 \mathrm{E}+05$ \\
\hline 67 & & & 10 & $E+06$ & $E+06$ & +06 & $61 \mathrm{E}+05$ & $E+06$ & $5.25 E+05$ \\
\hline 68 & & IGKC & 10 & $8.52 \mathrm{E}+06$ & $E+06$ & $E+06$ & $3.03 E+06$ & $E+06$ & $3.20 E+06$ \\
\hline 69 & & $\mathrm{ABP2}$ & 10 & $E+05$ & & & $1.64 \mathrm{E}+05$ & $E+05$ & $2.13 E+05$ \\
\hline 70 & & & 10 & $0 \mathrm{E}+05$ & +05 & $E+05$ & $74 \mathrm{E}+05$ & $2.68 \mathrm{E}+05$ & $1.24 \mathrm{E}+05$ \\
\hline 71 & & & 1 & $E+06$ & +06 & $E+06$ & $2.68 \mathrm{E}+05$ & $3.69 \mathrm{E}+05$ & $5.97 \mathrm{E}+05$ \\
\hline 72 & & & 10 & $9.65 E+05$ & $1.08 \mathrm{E}+06$ & & $2.82 \mathrm{E}+05$ & $2.98 \mathrm{E}+05$ & $3.40 \mathrm{E}+05$ \\
\hline 73 & & BPB2 & 10 & $7.73 E+05$ & $6.92 \mathrm{E}+05$ & $E+05$ & $1.36 \mathrm{E}+05$ & $2.16 \mathrm{E}+05$ & $1.29 E+05$ \\
\hline 74 & & PTR & 10 & $1.36 \mathrm{E}+06$ & $1.50 \mathrm{E}+06$ & $4 \mathrm{E}+06$ & $4.69 E+05$ & $8.75 E+05$ & $7.95 \mathrm{E}+05$ \\
\hline 75 & & NGT & 10 & $4.90 E+05$ & $6.94 \mathrm{E}+05$ & $7.47 E+05$ & $1.44 \mathrm{E}+05$ & $9.97 E+04$ & $3.35 E+05$ \\
\hline 76 & & & 10 & $2.62 \mathrm{E}+06$ & $1.80 \mathrm{E}+06$ & $9.84 \mathrm{E}+05$ & $1.90 \mathrm{E}+06$ & $1.53 \mathrm{E}+06$ & $6.13 E+05$ \\
\hline 77 & & & 10 & $6.15 E+05$ & $8.40 \mathrm{E}+05$ & $9.34 \mathrm{E}+05$ & $1.84 \mathrm{E}+05$ & $2.33 \mathrm{E}+05$ & $5.05 \mathrm{E}+05$ \\
\hline 78 & & C4BPB & 10 & $2.19 \mathrm{E}+06$ & $2.10 \mathrm{E}+06$ & $2.23 \mathrm{E}+06$ & $5.28 \mathrm{E}+05$ & $7.08 \mathrm{E}+05$ & $5.08 \mathrm{E}+05$ \\
\hline 79 & P01591 & & 10 & $2.84 \mathrm{E}+06$ & $2.53 \mathrm{E}+06$ & $5 E+06$ & $1.23 E+06$ & $7.40 \mathrm{E}+05$ & $1.50 \mathrm{E}+06$ \\
\hline 80 & & & 9 & $7.88 \mathrm{E}+06$ & $9.82 \mathrm{E}+06$ & $8.60 \mathrm{E}+06$ & $2.52 E+06$ & $4.66 \mathrm{E}+06$ & $2.65 E+06$ \\
\hline 81 & & & 9 & $3.44 \mathrm{E}+06$ & $3.96 \mathrm{E}+06$ & $3.43 E+06$ & $1.56 \mathrm{E}+06$ & $8.31 E+05$ & $5.64 \mathrm{E}+05$ \\
\hline 82 & P27918 & ROP & 9 & $4.69 E+05$ & $4.39 E+05$ & $9 \mathrm{E}+05$ & $9.39 E+04$ & $1.38 \mathrm{E}+05$ & $1.12 \mathrm{E}+05$ \\
\hline 83 & & & 9 & $4.52 E+05$ & $4.55 E+05$ & & $3.10 E+05$ & $2.62 \mathrm{E}+05$ & $2.91 \mathrm{E}+05$ \\
\hline 84 & & CO8G & 9 & $2.38 \mathrm{E}+06$ & $2.08 \mathrm{E}+06$ & $2.05 E+06$ & $4.15 E+05$ & $3.26 \mathrm{E}+05$ & $3.96 E+05$ \\
\hline 85 & P68871 & BBB & 8 & $8.85 E+05$ & $1.04 \mathrm{E}+06$ & $6.79 E+05$ & $3.32 \mathrm{E}+05$ & $4.11 \mathrm{E}+05$ & $2.41 E+05$ \\
\hline 86 & & & 8 & $3.44 E+06$ & & & $3.97 \mathrm{E}+05$ & $1.17 \mathrm{E}+06$ & $1.12 \mathrm{E}+06$ \\
\hline 87 & Q9BXR6 & FHR5 & 8 & $2.95 \mathrm{E}+05$ & $2.96 \mathrm{E}+05$ & $2.91 E+05$ & $6.75 E+04$ & $1.37 \mathrm{E}+05$ & $1.04 \mathrm{E}+05$ \\
\hline
\end{tabular}




\begin{tabular}{|c|c|c|c|c|c|c|c|c|c|}
\hline 88 & 02747 & $\mathrm{C} 1 \mathrm{QC}$ & 8 & $1.23 \mathrm{E}+06$ & $1.24 \mathrm{E}+06$ & $1.35 \mathrm{E}+06$ & $4.48 \mathrm{E}+05$ & $6.70 \mathrm{E}+05$ & $6.72 \mathrm{E}+05$ \\
\hline 89 & 19652 & $1 \mathrm{AG} 2$ & 8 & $5.84 \mathrm{E}+05$ & $6.08 \mathrm{E}+05$ & $5.14 \mathrm{E}+05$ & $1.14 \mathrm{E}+05$ & $1.85 \mathrm{E}+05$ & $1.19 \mathrm{E}+05$ \\
\hline 90 & 02652 & POA2 & 7 & $4.73 E+05$ & $5.65 \mathrm{E}+05$ & $4.92 E+05$ & $9.35 \mathrm{E}+04$ & $9.81 \mathrm{E}+04$ & $6.75 \mathrm{E}+04$ \\
\hline 91 & 02746 & $1 Q B$ & 7 & $9.06 \mathrm{E}+05$ & $9.57 \mathrm{E}+05$ & $1.03 E+06$ & $3.20 E+05$ & $5.34 \mathrm{E}+05$ & $4.90 E+05$ \\
\hline 92 & 69905 & IBA & 7 & $.02 \mathrm{E}+06$ & $.22 \mathrm{E}+06$ & $.11 \mathrm{E}+05$ & $4.09 \mathrm{E}+05$ & $4.48 \mathrm{E}+05$ & $43 \mathrm{E}+05$ \\
\hline 93 & Q06033 & ITIH3 & 7 & $8.00 E+04$ & $1.13 \mathrm{E}+05$ & $1.13 E+05$ & $2.07 E+04$ & $2.71 E+04$ & $3.35 E+04$ \\
\hline 94 & OCOL5 & CO4B & 6 & $1.36 \mathrm{E}+05$ & $1.37 \mathrm{E}+05$ & $2.31 E+05$ & $4.62 E+04$ & $9.73 \mathrm{E}+04$ & $7.21 \mathrm{E}+04$ \\
\hline 95 & 01857 & GHG1 & 6 & $2.95 \mathrm{E}+06$ & $2.12 \mathrm{E}+06$ & $.43 \mathrm{E}+06$ & $3.36 \mathrm{E}+06$ & $3.18 \mathrm{E}+06$ & $1.81 \mathrm{E}+06$ \\
\hline 96 & B9A064 & IGLL5 & 6 & $7.34 \mathrm{E}+05$ & $8.37 \mathrm{E}+05$ & $5.81 E+05$ & $4.21 E+05$ & $5.36 \mathrm{E}+05$ & $1.77 \mathrm{E}+05$ \\
\hline 97 & 00746 & CFAD & 6 & $6.39 E+05$ & $5.82 \mathrm{E}+05$ & $5.06 \mathrm{E}+05$ & $1.36 \mathrm{E}+05$ & $1.35 \mathrm{E}+05$ & $1.15 \mathrm{E}+05$ \\
\hline 98 & 95445 & APOM & 6 & $1.50 \mathrm{E}+05$ & $1.61 \mathrm{E}+05$ & $.46 \mathrm{E}+05$ & $3.95 E+04$ & $4.45 E+04$ & $96 \mathrm{E}+04$ \\
\hline 99 & 92 & CPN2 & 6 & $1.17 \mathrm{E}+05$ & $1.45 \mathrm{E}+05$ & $3+05$ & $4.49 E+04$ & $4.56 \mathrm{E}+04$ & $87 E+04$ \\
\hline 100 & 05543 & THBG & 6 & $1.49 \mathrm{E}+05$ & $1.82 \mathrm{E}+05$ & $1.68 \mathrm{E}+05$ & $3.32 E+04$ & $6.09 \mathrm{E}+04$ & $4.89 E+04$ \\
\hline 101 & 014791 & APOL1 & 6 & +05 & $2.30 \mathrm{E}+05$ & $5 \mathrm{E}+05$ & $5 \mathrm{E}+04$ & $8.08 \mathrm{E}+04$ & $55 \mathrm{E}+04$ \\
\hline 102 & P18428 & LBP & 6 & $1.35 \mathrm{E}+05$ & $1.42 \mathrm{E}+05$ & $\mathrm{DE}+05$ & $3.17 E+04$ & $3.96 \mathrm{E}+04$ & $0 \mathrm{E}+05$ \\
\hline 103 & P01859 & IGHG2 & 5 & $7.71 E+05$ & $5.27 \mathrm{E}+05$ & $6.64 \mathrm{E}+05$ & $7.03 E+05$ & $8.26 \mathrm{E}+05$ & $7.71 E+05$ \\
\hline 104 & 36 & & 5 & +06 & $E+06$ & $=06$ & $E+05$ & $E+06$ & $35 \mathrm{E}+06$ \\
\hline 105 & & & 5 & & +05 & +05 & +05 & $\mathrm{E}+05$ & $3 \mathrm{E}+05$ \\
\hline 106 & $\mathrm{P} 02$ & & 5 & $1.03 \mathrm{E}+06$ & $7.67 \mathrm{E}+05$ & $6 \mathrm{E}+05$ & $7.14 \mathrm{E}+05$ & $2.64 \mathrm{E}+05$ & $20 \mathrm{E}+05$ \\
\hline 107 & 49908 & EPP1 & 5 & $3.61 E+05$ & $3.78 \mathrm{E}+05$ & $9 E+05$ & $1.38 \mathrm{E}+05$ & $8.65 E+04$ & $65 E+05$ \\
\hline 108 & P61 & YSC & 5 & +05 & $=05$ & $=05$ & $=04$ & $E+04$ & $7 \mathrm{E}+04$ \\
\hline 109 & 075 & FCN3 & 5 & +05 & $E+05$ & $E+05$ & $7 \mathrm{E}+04$ & $6.11 E+04$ & $39 \mathrm{E}+04$ \\
\hline 110 & P17 & IBP3 & 5 & 3.99 & $\mathrm{DE}+05$ & $2 E+05$ & $1.45 \mathrm{E}+05$ & $9.77 \mathrm{E}+04$ & $7.90 \mathrm{E}+04$ \\
\hline 111 & & & 5 & +06 & $E+06$ & $E+06$ & $E+06$ & $6.17 \mathrm{E}+05$ & $5 \mathrm{E}+05$ \\
\hline 112 & 77 & IGHA2 & 5 & +05 & $6.94 \mathrm{E}+05$ & $2 \mathrm{E}+05$ & $\mathrm{E}+05$ & $4.03 E+05$ & $6 \mathrm{E}+05$ \\
\hline 113 & Q04 & HGFA & 5 & +05 & $1.59 \mathrm{E}+05$ & $7 \mathrm{E}+05$ & $\mathrm{E}+04$ & $5 \mathrm{E}+05$ & $1 \mathrm{E}+05$ \\
\hline 114 & & & 5 & & +04 & +05 & $E+04$ & $E+04$ & $9 \mathrm{E}+04$ \\
\hline 115 & & & 5 & & +05 & $=05$ & $=04$ & $E+04$ & $\mathrm{E}+04$ \\
\hline 116 & & LA & 4 & & +04 & $=05$ & $E+04$ & $E+04$ & $1 E+04$ \\
\hline 117 & 980 & & 4 & +05 & $E+05$ & $E+05$ & $\mathrm{E}+04$ & $5.73 \mathrm{E}+04$ & $.0 \mathrm{E}+05$ \\
\hline 118 & & & 4 & +04 & $=05$ & $E+05$ & $E+04$ & $1.57 \mathrm{E}+05$ & $2 \mathrm{E}+05$ \\
\hline 119 & P04220 & MUCB & 4 & $E+05$ & $\mathrm{E}+05$ & $7 \mathrm{E}+05$ & $1.89 \mathrm{E}+05$ & $2.10 \mathrm{E}+05$ & $35 \mathrm{E}+05$ \\
\hline 120 & & & 4 & & $E+05$ & $\mathrm{E}+05$ & $0 \mathrm{E}+05$ & $7.68 \mathrm{E}+04$ & $50 \mathrm{E}+05$ \\
\hline 121 & & & 4 & & +05 & $8+05$ & $E+04$ & $3.80 \mathrm{E}+04$ & $8 \mathrm{E}+04$ \\
\hline 122 & P02745 & C1QA & 4 & $1.65 \mathrm{E}+05$ & $1.71 \mathrm{E}+05$ & $4 \mathrm{E}+05$ & $6.83 \mathrm{E}+04$ & $1.06 \mathrm{E}+05$ & $3 E+04$ \\
\hline 123 & & L7 & 4 & & $E+05$ & $E+05$ & $8 \mathrm{E}+05$ & $1.73 \mathrm{E}+05$ & $2 \mathrm{E}+04$ \\
\hline 124 & & & 4 & +04 & $6.78 \mathrm{E}+04$ & $\mathrm{E}+04$ & $0 \mathrm{E}+04$ & $5.33 \mathrm{E}+04$ & $8 \mathrm{E}+04$ \\
\hline 126 & P0COL4 & & 4 & +05 & $1.84 \mathrm{E}+05$ & $9 \mathrm{E}+05$ & $.87 \mathrm{E}+04$ & $1.06 \mathrm{E}+05$ & $1 \mathrm{E}+05$ \\
\hline 127 & P01861 & IGHG4 & 4 & $2.79 E+05$ & $3.98 E+04$ & $3.42 E+04$ & $6.16 \mathrm{E}+05$ & $5.25 E+04$ & $58 \mathrm{E}+04$ \\
\hline 128 & & & 4 & $2.56 \mathrm{E}+04$ & $6.91 \mathrm{E}+04$ & $2 \mathrm{E}+05$ & $3.45 E+04$ & $5.55 \mathrm{E}+04$ & $34 \mathrm{E}+05$ \\
\hline 129 & P01 & & 4 & $2.98 \mathrm{E}+05$ & $3.08 \mathrm{E}+05$ & $5 \mathrm{E}+05$ & $2.85 \mathrm{E}+05$ & $5.59 \mathrm{E}+05$ & $47 E+05$ \\
\hline 130 & P22891 & PROZ & 4 & $5.53 \mathrm{E}+04$ & $5.16 \mathrm{E}+04$ & $8.28 \mathrm{E}+04$ & $4.03 E+04$ & $2.68 \mathrm{E}+04$ & $5.07 E+04$ \\
\hline 131 & & & 4 & $9.87 \mathrm{E}+04$ & $1.28 \mathrm{E}+05$ & $1 \mathrm{E}+05$ & $2.21 \mathrm{E}+04$ & $5.17 \mathrm{E}+04$ & $3.88 \mathrm{E}+04$ \\
\hline 125 & & & 3 & $6.08 \mathrm{E}+05$ & $7.50 \mathrm{E}+05$ & $3.55 \mathrm{E}+05$ & $1.14 \mathrm{E}+05$ & $1.60 \mathrm{E}+05$ & $1.21 \mathrm{E}+05$ \\
\hline 132 & P01764 & & 3 & $1.37 \mathrm{E}+05$ & $1.02 \mathrm{E}+05$ & $1.81 \mathrm{E}+05$ & $9.61 \mathrm{E}+04$ & $4.48 \mathrm{E}+04$ & $2.35 \mathrm{E}+05$ \\
\hline 133 & P35542 & & 3 & $7.16 \mathrm{E}+05$ & $6.77 \mathrm{E}+05$ & $7 \mathrm{E}+05$ & $2.14 \mathrm{E}+05$ & $1.93 \mathrm{E}+05$ & $1.26 \mathrm{E}+05$ \\
\hline 134 & & & 3 & $1.51 \mathrm{E}+05$ & $7.72 \mathrm{E}+04$ & $6.45 \mathrm{E}+04$ & $1.80 \mathrm{E}+05$ & $4.65 E+04$ & $3.17 E+04$ \\
\hline 135 & P06310 & & 3 & $2.26 \mathrm{E}+05$ & $2.11 E+05$ & $1.57 \mathrm{E}+05$ & $8.52 \mathrm{E}+04$ & $1.01 \mathrm{E}+05$ & $5.30 \mathrm{E}+04$ \\
\hline 136 & P11226 & MBL2 & 3 & $1.12 \mathrm{E}+05$ & $8.37 E+04$ & $1.28 \mathrm{E}+05$ & $7.31 E+04$ & $5.64 \mathrm{E}+04$ & $1.04 \mathrm{E}+05$ \\
\hline 137 & P0DJI8 & SAA1 & 3 & $9.76 \mathrm{E}+04$ & $1.49 \mathrm{E}+05$ & $2.14 \mathrm{E}+05$ & $8.56 \mathrm{E}+04$ & $1.33 \mathrm{E}+05$ & $2.75 \mathrm{E}+05$ \\
\hline
\end{tabular}




\begin{tabular}{|c|c|c|c|c|c|c|c|c|c|}
\hline 138 & 06313 & KV403 & 3 & $1.19 \mathrm{E}+06$ & $1.05 E+06$ & $1.43 \mathrm{E}+06$ & $4.07 \mathrm{E}+05$ & $3.99 \mathrm{E}+05$ & $7.06 \mathrm{E}+05$ \\
\hline 139 & 75882 & ATRN & 3 & $1.29 E+04$ & $1.66 \mathrm{E}+04$ & $1.28 \mathrm{E}+04$ & $2.21 E+03$ & $6.71 E+03$ & $2.99 E+03$ \\
\hline 140 & 02654 & POC1 & 3 & $.28 \mathrm{E}+05$ & $5.97 E+05$ & $5.05 \mathrm{E}+05$ & $4.00 E+05$ & $3.29 E+05$ & $2.61 \mathrm{E}+05$ \\
\hline 141 & 15113 & COC1 & 3 & $1.90 \mathrm{E}+05$ & $.04 \mathrm{E}+05$ & $1.59 \mathrm{E}+05$ & $37 E+04$ & $08 \mathrm{E}+05$ & $99 \mathrm{E}+04$ \\
\hline 142 & 15582 & $\mathrm{BGH} 3$ & 3 & $2.88 \mathrm{E}+04$ & $2.98 \mathrm{E}+04$ & $2.58 \mathrm{E}+04$ & $5.76 \mathrm{E}+03$ & $6.69 \mathrm{E}+03$ & $3.54 \mathrm{E}+03$ \\
\hline 143 & 02985 & HR3 & 3 & $8.43 E+04$ & $6.06 \mathrm{E}+04$ & $1.07 E+05$ & $2.76 \mathrm{E}+04$ & $.76 \mathrm{E}+04$ & $9 \mathrm{E}+04$ \\
\hline 144 & P80108 & & 3 & & $6.67 E+04$ & $4.28 \mathrm{E}+04$ & $1.08 \mathrm{E}+04$ & $33 E+04$ & $0 \mathrm{E}+04$ \\
\hline 145 & P08571 & D14 & 3 & $4.64 \mathrm{E}+04$ & $5.38 \mathrm{E}+04$ & $4.82 \mathrm{E}+04$ & $1.57 \mathrm{E}+04$ & $1.94 \mathrm{E}+04$ & $7 E+04$ \\
\hline 146 & 08185 & $B G$ & 3 & $E+04$ & $1.07 \mathrm{E}+05$ & $1.10 \mathrm{E}+05$ & $2.64 \mathrm{E}+04$ & $.94 E+04$ & $\overline{\mathrm{OE}+04}$ \\
\hline 147 & & & 3 & & $.10 \mathrm{E}+05$ & $E+05$ & $E+04$ & $3 \mathrm{E}+03$ & \\
\hline 148 & & & 3 & & $2.02 E+04$ & $1.89 \mathrm{E}+04$ & $1 E+03$ & $0 \mathrm{E}+03$ & $E+03$ \\
\hline 149 & P63261 & CTG & 3 & $3.68 \mathrm{E}+04$ & $5.10 \mathrm{E}+04$ & $3.23 E+04$ & $9.76 \mathrm{E}+03$ & $1.30 \mathrm{E}+04$ & $\mathrm{OE}+03$ \\
\hline 150 & 996 & $T$ & 3 & +04 & $5.61 \mathrm{E}+04$ & $3 E+04$ & $E+04$ & $6 \mathrm{E}+04$ & +04 \\
\hline 151 & 278 & G & 2 & & $3.65 E+04$ & $4.25 E+04$ & $5 \mathrm{E}+03$ & $2 E+04$ & +04 \\
\hline 152 & P06316 & 07 & 2 & & $7.30 \mathrm{E}+04$ & $5 \mathrm{E}+04$ & $3 \mathrm{E}+04$ & $8 \mathrm{E}+04$ & $3 \mathrm{E}+04$ \\
\hline 153 & & & 2 & & $E+04$ & +05 & +04 & $E+04$ & \\
\hline 154 & & & 2 & & $E+02$ & +02 & & $E+02$ & \\
\hline 155 & & & 2 & & $5 \mathrm{E}+05$ & $E+05$ & $=04$ & $E+04$ & $E+04$ \\
\hline 156 & 05160 & $13 B$ & 2 & & $5.99 \mathrm{E}+04$ & $\mathrm{E}+04$ & $=04$ & $1 \mathrm{E}+04$ & $E+04$ \\
\hline 157 & & & 2 & & $4.85 \mathrm{E}+03$ & $3.97 \mathrm{E}+03$ & +03 & $3 E+03$ & $E+03$ \\
\hline 158 & P0CG06 & LAC3 & 2 & +04 & $1.28 \mathrm{E}+04$ & $1.47 \mathrm{E}+04$ & $8.48 \mathrm{E}+03$ & $9 \mathrm{E}+04$ & $7 \mathrm{E}+03$ \\
\hline 159 & & & 2 & & $4.68 \mathrm{E}+05$ & $\mathrm{E}+05$ & $1.79 E+05$ & $4 \mathrm{E}+05$ & $8 \mathrm{E}+05$ \\
\hline 160 & & & 2 & & $5.68 \mathrm{E}+04$ & $\mathrm{E}+04$ & $E+04$ & $7 E+04$ & $E+04$ \\
\hline 161 & 48 & $\sqrt{302}$ & 2 & $E+05$ & $6.69 E+05$ & $6.81 \mathrm{E}+05$ & $2.26 \mathrm{E}+05$ & $3 E+05$ & $E+05$ \\
\hline 162 & & & 2 & & $2.71 E+04$ & $\mathrm{DE}+04$ & $\mathrm{E}+03$ & $6 \mathrm{E}+04$ & $\mathrm{E}+03$ \\
\hline 163 & & & 2 & $E+04$ & $6.52 \mathrm{E}+04$ & $9 \mathrm{E}+04$ & $6.72 \mathrm{E}+04$ & $1 \mathrm{E}+04$ & $6 \mathrm{E}+04$ \\
\hline 164 & & & 2 & +04 & $2.05 E+04$ & $6 \mathrm{E}+04$ & $4.75 E+03$ & $1 \mathrm{E}+04$ & $E+03$ \\
\hline 165 & & & 2 & & $2.60 \mathrm{E}+05$ & $2.29 E+05$ & $8.18 \mathrm{E}+04$ & $1 \mathrm{E}+05$ & $1.70 \mathrm{E}+05$ \\
\hline 166 & P04433 & V309 & 2 & $7.68 \mathrm{E}+04$ & $7.35 \mathrm{E}+04$ & $8.07 E+04$ & $2.42 E+04$ & $30 \mathrm{E}+04$ & $9.33 \mathrm{E}+04$ \\
\hline 167 & & & 2 & $\mathrm{E}+04$ & $2.50 \mathrm{E}+04$ & $3.19 E+04$ & $1.29 \mathrm{E}+04$ & $1.29 \mathrm{E}+04$ & $2.12 \mathrm{E}+04$ \\
\hline 168 & & & 2 & & $3.85 E+03$ & $4.87 E+03$ & $9.69 \mathrm{E}+05$ & $1.84 \mathrm{E}+03$ & $2.44 \mathrm{E}+03$ \\
\hline 169 & P01779 & V318 & 2 & $3 \mathrm{E}+05$ & $6.51 \mathrm{E}+05$ & $9.21 \mathrm{E}+05$ & $4.41 E+05$ & $0 \mathrm{E}+05$ & $8.95 E+05$ \\
\hline 170 & & & 2 & & $2.60 \mathrm{E}+04$ & $2.43 E+04$ & $6.32 \mathrm{E}+03$ & $1.22 \mathrm{E}+04$ & $1.18 \mathrm{E}+04$ \\
\hline 171 & & & 2 & & $1.52 \mathrm{E}+04$ & $1.09 \mathrm{E}+04$ & $1.98 \mathrm{E}+03$ & $5.36 \mathrm{E}+03$ & $4.68 \mathrm{E}+03$ \\
\hline 172 & P22352 & GPX3 & 2 & $6.27 \mathrm{E}+04$ & $1.02 \mathrm{E}+05$ & $7.60 \mathrm{E}+04$ & $1.53 \mathrm{E}+04$ & $2.86 \mathrm{E}+04$ & $2.71 \mathrm{E}+04$ \\
\hline 173 & & & 2 & & $1.10 \mathrm{E}+04$ & $8.34 \mathrm{E}+03$ & & $6.07 \mathrm{E}+03$ & $1.51 \mathrm{E}+03$ \\
\hline 174 & Q13790 & APOF & 2 & $1.96 \mathrm{E}+04$ & $2.63 \mathrm{E}+04$ & $2.16 \mathrm{E}+04$ & $8.19 \mathrm{E}+03$ & $6.30 \mathrm{E}+03$ & $7.20 \mathrm{E}+03$ \\
\hline
\end{tabular}


Table S3: List of HAP binding plasma proteins displaying a statistically significant difference (pvalue $<0.05$ ) in abundance between male and female participants.

\begin{tabular}{|l|l|l|l|l|l|}
\hline No. & Uniprot ID & $\begin{array}{l}\text { Uniprot } \\
\text { name }\end{array}$ & Group & $\begin{array}{l}\text { Fold change } \\
\text { Male/Female }\end{array}$ & -value \\
\hline 1 & P20742 & PZP & Pregnancy zone protein & 0.25 & $3.88 \mathrm{E}-03$ \\
\hline 2 & P06702 & S10A9 & Protein S100-A9 & 2.95 & $1.70 \mathrm{E}-02$ \\
\hline 3 & P01877 & IGHA2 & Ig alpha-2 chain C region & 1.94 & $2.10 \mathrm{E}-02$ \\
\hline 4 & P01034 & CYTC & Cystatin-C & 1.40 & $2.24 \mathrm{E}-02$ \\
\hline 5 & P01624 & KV306 & Ig kappa chain V-III region POM & 1.92 & $2.36 \mathrm{E}-02$ \\
\hline 6 & P00746 & CFAD & Complement factor D & 1.29 & $3.67 \mathrm{E}-02$ \\
\hline 7 & Q96IY4 & CBPB2 & Carboxypeptidase B2 & 1.24 & $4.81 \mathrm{E}-02$ \\
\hline
\end{tabular}


Figure S1: Principal component analysis of SWATH-MS data from technical duplicates of HAPeluted plasma samples from all participants. Points are labelled with the participant number (as given in Table S1). Samples were also designated as replicate " $a$ " or " $b$ " and assigned to their respective CFH genotypic group; T/T1277 (TT), T/C1277 (CT) or C/C1277 (CC).

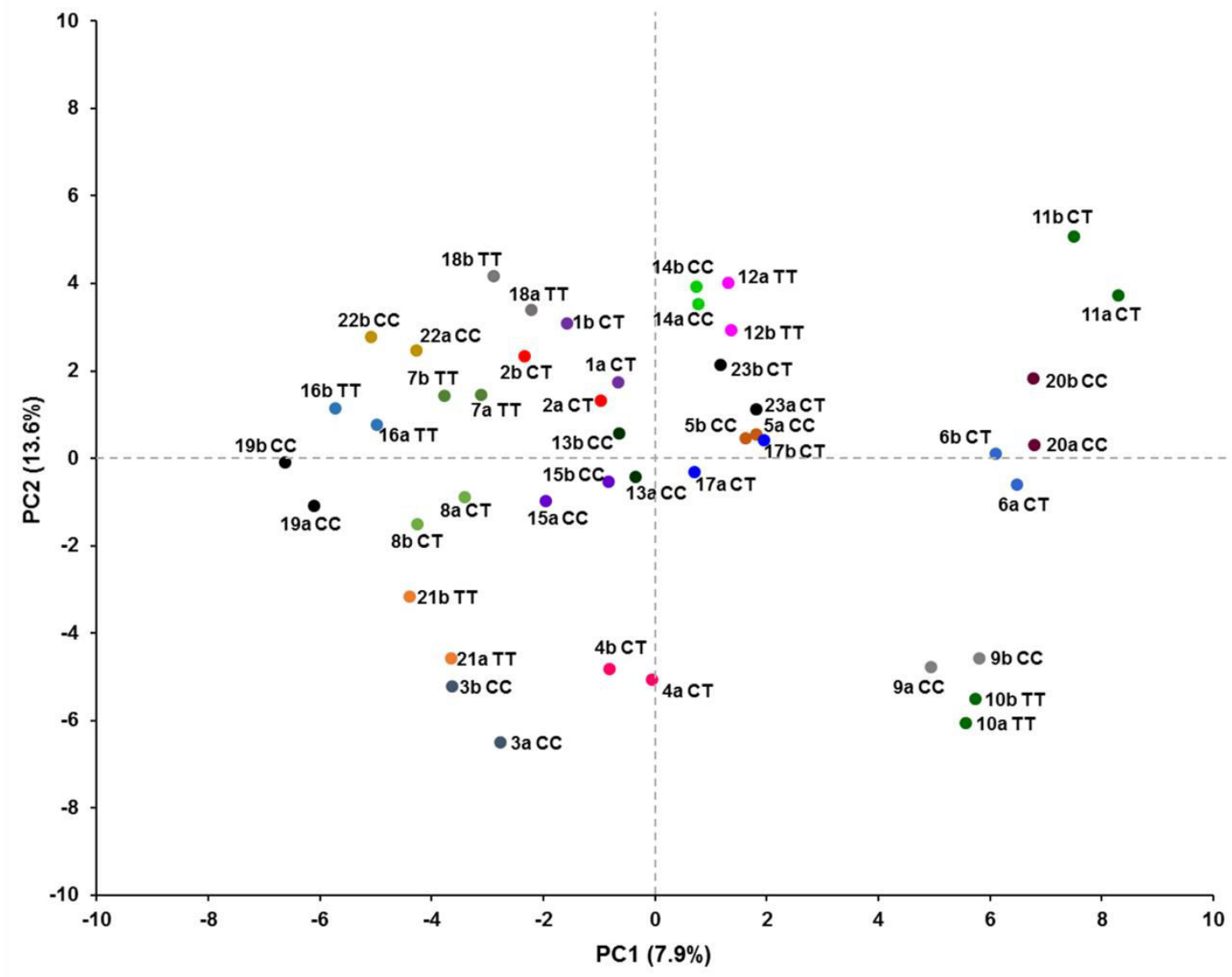

